\title{
Review \\ Cyclodextrin-Containing Hydrogels: A Review of Preparation Method, Drug Delivery, and Degradation Behavior
}

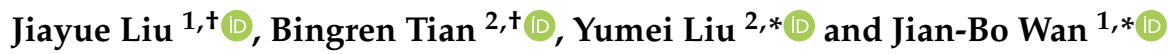 \\ 1 State Key Laboratory of Quality Research in Chinese Medicine, Institute of Chinese Medical Sciences, \\ University of Macau, Macao 999078, China; liujiayue0331@163.com \\ 2 School of Chemical Engineering and Technology, Xinjiang University, Urumqi 830046, China; \\ tianbingren1@163.com \\ * Correspondence: xjdxlym@xju.edu.cn (Y.L.); jbwan@um.edu.mo (J.-B.W.); Tel.: +853-88224680 (J.-B.W) \\ + These authors contributed equally to this work and should be considered co-first authors.
}

check for updates

Citation: Liu, J.; Tian, B.; Liu, Y.; Wan, J.-B. Cyclodextrin-Containing Hydrogels: A Review of Preparation Method, Drug Delivery, and Degradation Behavior. Int. J. Mol. Sci. 2021, 22, 13516. https://doi.org/ 10.3390/ijms222413516

Academic Editor: Yury A. Skorik

Received: 6 November 2021

Accepted: 14 December 2021

Published: 16 December 2021

Publisher's Note: MDPI stays neutral with regard to jurisdictional claims in published maps and institutional affiliations.

Copyright: (c) 2021 by the authors. Licensee MDPI, Basel, Switzerland. This article is an open access article distributed under the terms and conditions of the Creative Commons Attribution (CC BY) license (https:// creativecommons.org/licenses/by/ $4.0 /)$.

\begin{abstract}
Hydrogels possess porous structures, which are widely applied in the field of materials and biomedicine. As a natural oligosaccharide, cyclodextrin (CD) has shown remarkable application prospects in the synthesis and utilization of hydrogels. CD can be incorporated into hydrogels to form chemically or physically cross-linked networks. Furthermore, the unique cavity structure of CD makes it an ideal vehicle for the delivery of active ingredients into target tissues. This review describes useful methods to prepare CD-containing hydrogels. In addition, the potential biomedical applications of CD-containing hydrogels are reviewed. The release and degradation process of CD-containing hydrogels under different conditions are discussed. Finally, the current challenges and future research directions on CD-containing hydrogels are presented.
\end{abstract}

Keywords: cyclodextrin; hydrogel; preparation; release; degradation

\section{Introduction}

Many studies in the material science field have explored diverse materials that could improve drug delivery, thus ensuring effective treatment of various diseases [1,2]. In the past few decades, numerous materials have been synthesized and applied in drug delivery systems [3,4]. Particularly, several clinical trials have explored the development of hydrogels and their potential applications [5]. The physical properties of hydrogels are biocompatible to organisms. Therefore, they have become indispensable materials in several biomedical applications [6]. Hydrophilic groups present in the hydrogel network enable the hydrogel to interact with water molecules in the surrounding environment. As a result, the hydrogel can absorb large amounts of water to maintain its structure and viscoelasticity. The volume changes of hydrogels can be controlled by changing parameters such as composite molecules and cross-linking density in different environments. Hydrogels are mainly synthesized in the water phase, therefore the introduction of cross-linking points throughout the hydrogel network is important in preventing the hydrogel from dissolving. According to the different cross-linking properties in the hydrogel network, hydrogels are mainly divided into two categories, including physical and chemical crosslinked hydrogels [7,8]. Physically cross-linked hydrogels are formed through physical interactions between the polymers that form hydrogels. On the other hand, chemically cross-linked hydrogels are formed by covalent bonds.

These properties enable the use of hydrogels as macromolecular platforms in drug delivery, wound healing dressings, and implant coatings [9-11]. Previous studies developed controllable, localized drug release systems for hydrogel systems [12,13]. Commonly used methods for drug loading include forming unstable chemical bonds to covalently bind drug molecules to the hydrogel matrix or employing non-covalent methods to encapsulate drug molecules into the hydrogel. Although the hydrogel can effectively control the release time 
when the drug is loaded through a covalent method, the synthesis process and the loading amount of the drug are not satisfactory [14,15]. On the contrary, physically trapping drug molecules into the hydrogel is simpler, and results in a hydrogel with a higher drug loading capacity. Drugs are mainly loaded to hydrogels through hydrophobic, electrostatic, or hydrogen bond interactions. However, most hydrogels are hydrophilic in nature, therefore, loading some hydrophobic drugs is not effective. Bringing hydrophobic regions into the hydrogel network can increase drug loading capacity and reduce the burst effect of the drug at the initial stage of entering the body [16-18].

Cyclodextrin (CD) is a cyclic oligosaccharide consisting of glucopyranoside units linked through $\alpha-1,4$ glycosidic bonds obtained [19]. Structural analysis shows that CD is characterized by external hydrophilicity and internal hydrophobicity. Due to its unique cavity structure, hydrophobic molecules can be loaded to form an inclusion complex in dynamic equilibrium [19]. Because of several hydroxyl groups existing in the external structure, CD could form physically cross-linked hydrogel through intermolecular forces. In addition, $\mathrm{CD}$ can be connected to form a chemically cross-linked hydrogel network through covalent bonds. Several studies have explored these two different types of CDcontaining hydrogels $[2,20]$.

Although CD-containing hydrogels are still in the basic research stage, they have prominent advantages in different applications [21-26] and remarkable potential in biomedical applications, thus improving human health (Table 1). This review is aimed to discuss and summarize the development of CD-containing hydrogels in drug delivery. The traits of hydrogels are classified and discussed based on the different preparation methods. Furthermore, the potential applications of these hydrogels are summarized. In addition, the release rate of drugs and degradation of hydrogels are explored. Further, we summarize prospects for the future development of CD-containing hydrogels based on previous research findings.

Table 1. Comparison of cyclodextrin-containing hydrogels with other types of hydrogels.

\begin{tabular}{|c|c|c|c|c|c|c|c|}
\hline $\begin{array}{l}\text { Material for } \\
\text { Forming } \\
\text { Hydrogel }\end{array}$ & Cyclodextrin & Chitosan & Cellulose & Alginic Acid & Gum Arabic & $\begin{array}{l}\text { Polyacryl } \\
\text { Amide }\end{array}$ & $\begin{array}{l}\text { Polyvinyl } \\
\text { Alcohol }\end{array}$ \\
\hline Source & Starch & Chitin & Plant & Alga & Acacia trees & Acrylonitrile & Vinyl acetate \\
\hline $\begin{array}{l}\text { Connection } \\
\text { type }\end{array}$ & $\begin{array}{c}\alpha-1, \\
4-\text { glycosidic } \\
\text { bond }\end{array}$ & $\begin{array}{c}\beta-1, \\
\text { 4-glycosidic } \\
\text { bond }\end{array}$ & $\begin{array}{c}\beta-1, \\
\text { 4-glycosidic } \\
\text { bond }\end{array}$ & $\begin{array}{l}\text { 1, 4-glycosidic } \\
\text { bond }\end{array}$ & - & - & - \\
\hline Techniques & $\begin{array}{l}\text { Radical poly- } \\
\text { merization; } \\
\text { Click reaction; } \\
\text { Nucleophilic } \\
\text { addition/ } \\
\text { substitution }\end{array}$ & $\begin{array}{l}\text { Photo- poly- } \\
\text { merization; } \\
\text { Thermal poly- } \\
\text { merization }\end{array}$ & $\begin{array}{l}\text { Chemical } \\
\text { crosslinking; } \\
\text { Free-radical } \\
\text { polymeriza- } \\
\text { tion; Grafting; } \\
\text { Freeze-thaw }\end{array}$ & $\begin{array}{l}\text { Enzymatically } \\
\text { crosslinking; } \\
\text { Chemical } \\
\text { crosslinking }\end{array}$ & $\begin{array}{l}\text { Photo-induced } \\
\text { radical poly- } \\
\text { merization }\end{array}$ & $\begin{array}{l}\text { Radiation- } \\
\text { induced }\end{array}$ & Freeze-thaw \\
\hline $\begin{array}{l}\text { Kinds of drug } \\
\text { delivery }\end{array}$ & $\begin{array}{l}\text { Hydrophobic } \\
\text { drug }\end{array}$ & $\begin{array}{l}\text { Small } \\
\text { molecules; } \\
\text { peptides; } \\
\text { proteins }\end{array}$ & $\begin{array}{l}\text { Small } \\
\text { molecules; } \\
\text { peptides; } \\
\text { proteins }\end{array}$ & $\begin{array}{l}\text { Traditional } \\
\text { low-molecular- } \\
\text { weight drugs } \\
\text { and macro- } \\
\text { molecules }\end{array}$ & $\begin{array}{l}\text { Small } \\
\text { molecules; } \\
\text { proteins }\end{array}$ & $\begin{array}{l}\text { Small } \\
\text { molecules; } \\
\text { peptides; } \\
\text { proteins }\end{array}$ & $\begin{array}{l}\text { Small } \\
\text { molecules; } \\
\text { peptides; } \\
\text { proteins }\end{array}$ \\
\hline Clinic trial & Yes & Yes & Yes & Yes & No & Yes & Yes \\
\hline Ref. & [27-29] & {$[30,31]$} & {$[32,33]$} & {$[34,35]$} & [36] & {$[37,38]$} & [39] \\
\hline
\end{tabular}

\section{Preparation Methods of CD-Containing Hydrogels}

Studies on the use of the unique cavity of $\mathrm{CD}$ to encapsulate and deliver drugs are ongoing [40-42]. CD hydrogels can be divided into two groups including physically crosslinked hydrogels and chemically cross-linked hydrogels (Figure 1). 


\section{Physically cross-linked hydrogels}
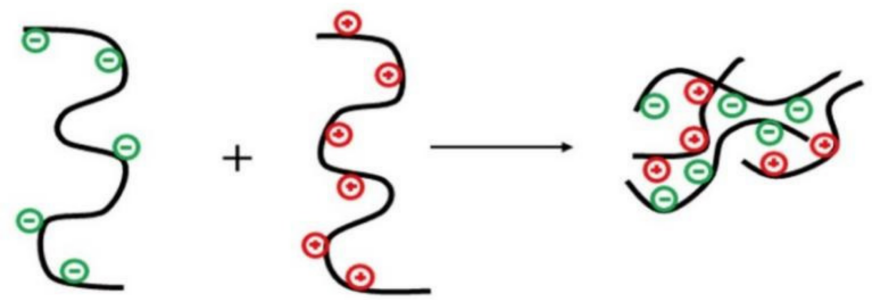

Polyanion

Polycation

Hydrogel (ionic reaction)

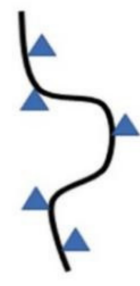

Donors

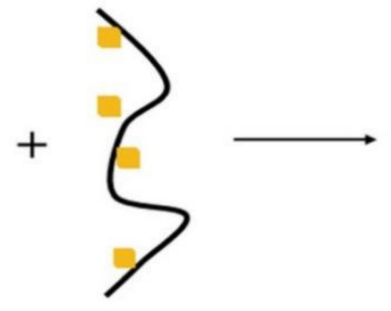

Acceptors

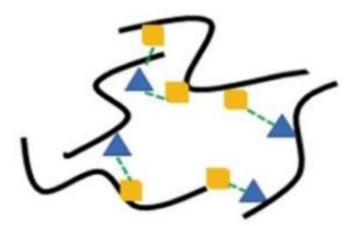

Hydrogel (hydrogen bonding)

\section{Chemically cross-linked hydrogels}

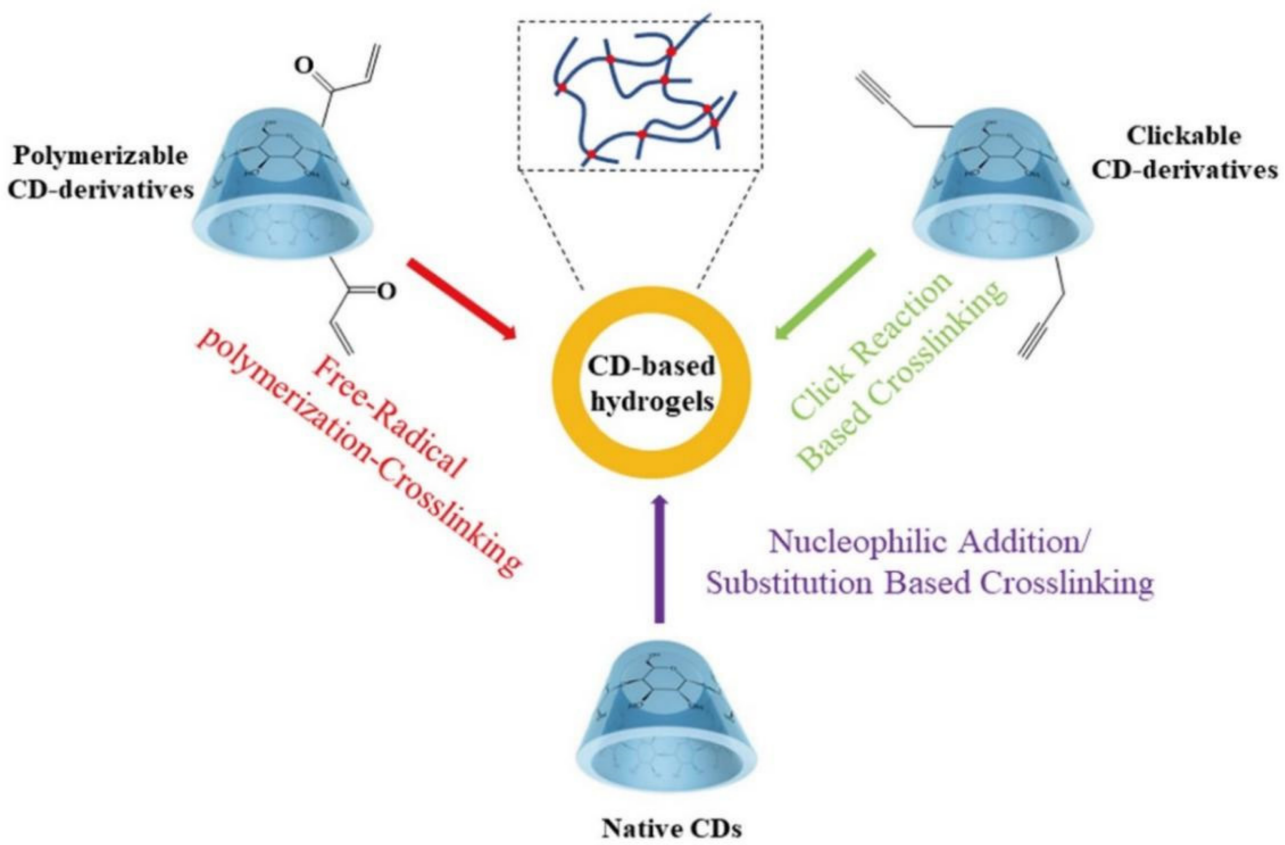

Figure 1. Schematic representation of common methodologies for preparation of CD-containing hydrogels.

Table 2 summarizes some examples of the preparation methods of physically crosslinked or chemically cross-linked cyclodextrin-containing hydrogels. Although physical hydrogels are non-toxic, they still have some shortcomings, such as low mechanical strength, and their pore size cannot be easily adjusted [43]. Physically cross-linked hydrogels are stable enough to prevent them from dissolving in water [44,45]. The methods involved in chemical cross-linking include free radical polymerization cross-linking-based methods; nucleophilic addition/substitution-based methods; cross-linking methods based on 'click' 
reactions and incorporation of CDs through post-gelation attachment [2]. The chemical activity produces permanent hydrogels through the covalent interaction of polymer and crosslinker functional groups. Polymerization into a hydrogel network produces fine-tuned hydrogels through chain growth, addition, or condensation reactions [46,47].

Table 2. The preparation methods of cyclodextrin-containing hydrogels.

\begin{tabular}{|c|c|c|c|c|}
\hline Types & Matrix & Preparation Methods & Characteristic & Ref. \\
\hline \multirow{10}{*}{$\begin{array}{l}\text { Physically cross-linked } \\
\text { cyclodextrin-containing } \\
\text { hydrogels }\end{array}$} & Chitosan & Casting method & Bilayer hydrogels & [48] \\
\hline & Chitosan & Freeze-thaw cycling method & pH sensitivity & [49] \\
\hline & Chitosan & Freezing method & $\begin{array}{l}\text { Thermosensitive; Shortly } \\
\text { gelation time ( } 3 \text { min or less) }\end{array}$ & [50] \\
\hline & Chitosan/Poly(Vinyl Alcohol) & Dry at room temperature in vacuo & $\mathrm{pH}$-specific release behavior & [51] \\
\hline & Gellan gum & Gelation at room temperature & Biocompatible material & [52] \\
\hline & $\begin{array}{l}\text { Hydroxypropyl } \\
\text { methylcellulose }\end{array}$ & Dispersion method & Benefit for skin & [53] \\
\hline & Nanocellulose & $\begin{array}{c}30 \text { min with autoclaving }\left(121^{\circ} \mathrm{C}, 103\right. \\
\mathrm{kPa})\end{array}$ & Sustained release & [54] \\
\hline & poly (vinyl alcohol) & Freezing drying method & Long-term release & [55] \\
\hline & Soy soluble polysaccharide & $\begin{array}{c}\text { Reduced pressure and stored in a } \\
\text { desiccator }\end{array}$ & $\begin{array}{l}\text { 3D-nanocomposites, } \\
\text { superabsorbent, malleable, } \\
\text { bioadhesive }\end{array}$ & [56] \\
\hline & Xanthan & Freezing drying method & Long-term release & [57] \\
\hline \multirow{10}{*}{$\begin{array}{l}\text { Chemically cross-linked } \\
\text { cyclodextrin-containing } \\
\text { hydrogels }\end{array}$} & $\begin{array}{l}\text { 4-arm-Polyethylene } \\
\text { glycol-Succinimidyl Glutarate }\end{array}$ & $\begin{array}{l}\text { Nucleophilic substitution-based } \\
\text { method }\end{array}$ & $\begin{array}{l}\text { Improved the } \\
\text { therapeutic effect }\end{array}$ & [58] \\
\hline & Agarose gel & $\begin{array}{l}\text { Nucleophilic substitution-based } \\
\text { method }\end{array}$ & $\begin{array}{l}\text { Low gelling temperature for } \\
\text { controlled drug delivery }\end{array}$ & [59] \\
\hline & Carboxymethyl cellulose & $\begin{array}{l}\text { Free radical polymerization } \\
\text { crosslinking-based method }\end{array}$ & $\mathrm{pH}$-responsive behaviour & [60] \\
\hline & Carboxymethyl cellulose & $\begin{array}{l}\text { Nucleophilic substitution-based } \\
\text { method }\end{array}$ & $\begin{array}{l}\text { Biocompatible, capable of } \\
\text { controlling the release for a } \\
\text { long duration }\end{array}$ & [61] \\
\hline & Chitosan & $\begin{array}{l}\text { Nucleophilic substitution-based } \\
\text { method }\end{array}$ & Local antibiotic release & [62] \\
\hline & Nanocellulose & $\begin{array}{l}\text { Nucleophilic substitution-based } \\
\text { method }\end{array}$ & $\begin{array}{l}\text { Cell compatibility, } \\
\text { non-cytotoxicity }\end{array}$ & [63] \\
\hline & $\begin{array}{l}\text { Polyvinyl } \\
\text { alcohol }\end{array}$ & $\begin{array}{l}\text { Nucleophilic substitution-based } \\
\text { method }\end{array}$ & $\begin{array}{l}\text { Good strength, elasticity, WVP, } \\
\text { and swelling ability }\end{array}$ & [64] \\
\hline & Poly(N-isopropylacrylamide) & $\begin{array}{l}\text { Free radical polymerization } \\
\text { crosslinking-based method }\end{array}$ & Thermoresponsive & [65] \\
\hline & $\begin{array}{l}\text { Poly(2-hydroxyethyl } \\
\text { methacrylate) }\end{array}$ & $\begin{array}{l}\text { Nucleophilic substitution-based } \\
\text { method }\end{array}$ & $\begin{array}{l}\text { Sustained drug } \\
\text { delivery }\end{array}$ & [66] \\
\hline & Sodium hyaluronan & $\begin{array}{l}\text { Nucleophilic substitution-based } \\
\text { method }\end{array}$ & Controlled release & [67] \\
\hline
\end{tabular}

In addition, hydroxyl groups occur at different positions in the CD molecule, thus they have different effects on the formed derivatives [68]. CD formed from glucopyranose has two types of hydroxyl groups, one is the primary hydroxyl group at the 6- position and the other is the secondary hydroxyl group at the 2- and 3- positions [69]. On the other hand, the primary hydroxyl group outside the cyclodextrin is free to move. In addition, the acidic and basic properties of the three hydroxyl groups are significantly different. The hydroxyl group at the 6- position is basic; the hydroxyl group at the 2- position is acidic ( $\mathrm{pKa}=12.1$ ), whereas the 3- hydroxyl group is not easily modified. Therefore, the chemical modification process of $\mathrm{CD}$ is affected by the nucleophilicity of the hydroxyl group and the modification reagent. Under normal reaction conditions, the 6-position hydroxyl group is the most active and easily participates in the reaction after attack by electrophiles. Electrophiles 
can also attack other positions, including the less popular hydroxyl groups (2- and 3-). More than $40 \%$ of the compounds have low water-solubility properties. In addition, some compounds have poor stability or poor taste [70-72]. CD has become the ideal material to solve solubility, light stability, and poor taste limitations. Different CDs have different sizes of hydrophobic cavities, so it is important to choose specific CD derivatives based on the molecular size of the target molecule [73]. Owing to the low solubility of parent $\mathrm{CD}$, its further application in medicine was limited. The preparation of water-soluble derivatives is important for improving the application of $\mathrm{CD}$ in drug delivery systems. Therefore, different CD-based derivatives have been developed to improve water solubility and functionality of natural CD.

\section{The Promising Application of CD-Containing Hydrogels for Drug Delivery}

In this section, we classify and discuss different types of CD-containing hydrogels based on the preparation method (Table 3). The release behavior of drugs after the introduction of different $\mathrm{CD}$ into hydrogels will be explored. Besides, the potential application of the prepared physical/chemical CD-containing hydrogel in the medical field will be discussed.

Table 3. Comparison of the properties of CD-containing hydrogels loaded with drugs [74-79].

\begin{tabular}{|c|c|c|}
\hline Property & $\begin{array}{c}\text { Physical Cross-Linked } \\
\text { Hydrogel }\end{array}$ & $\begin{array}{c}\text { Chemical Cross-Linked } \\
\text { Hydrogel }\end{array}$ \\
\hline Size of guest molecules & Small molecules (lipophilic) & Small molecules (lipophilic) \\
\hline Drug loading strategies & Encapsulation & Encapsulation \\
\hline Drug release speed & Can be controlled & Can be controlled \\
\hline $\begin{array}{l}\text { Drug release possible } \\
\text { mechanisms }\end{array}$ & $\begin{array}{c}\text { External stimulus; } \\
\text { competition of external } \\
\text { molecules }\end{array}$ & $\begin{array}{c}\text { External stimulus; } \\
\text { competition of external } \\
\text { molecule }\end{array}$ \\
\hline Duration times & Hours to days & Days to months \\
\hline Drug delivery characteristic & $\begin{array}{c}\text { High drug loading effectivity; } \\
\text { low chance of drug } \\
\text { deactivation }\end{array}$ & $\begin{array}{c}\text { High drug loading effectivity; } \\
\text { low chance of drug } \\
\text { deactivation }\end{array}$ \\
\hline Potential application & $\begin{array}{l}\text { Drug delivery systems, } \\
\text { injectable, wound dressings }\end{array}$ & $\begin{array}{l}\text { Transdermal drug delivery, } \\
\text { injectable, implantable, } \\
\text { oral/ophthalmic drug carrier }\end{array}$ \\
\hline Advantages & $\begin{array}{l}\text { Non-toxic; cross-linking is } \\
\text { reversible }\end{array}$ & $\begin{array}{l}\text { Strong mechanical strength; } \\
\text { the pore size can be adjusted; } \\
\text { the variety of synthesis } \\
\text { methods; difficult to degrade }\end{array}$ \\
\hline Disadvantages & $\begin{array}{l}\text { Low mechanical strength; } \\
\text { difficult to adjust the pore size }\end{array}$ & $\begin{array}{l}\text { Potentially toxic; no } \\
\text { cross-linking is reversible }\end{array}$ \\
\hline
\end{tabular}

\subsection{Physically Cross-Linked CD-Containing Hydrogels}

The physically cross-linked hydrogel formed by intermolecular interaction does not cause damage to the environment during the preparation process $[49,80]$. Therefore, physically cross-linked hydrogels have wide applications in the medical field. This section mainly summarizes and analyzes potential applications of physically cross-linked CDcontaining hydrogels loaded with different drugs in different medical fields (Table 4). Because in the process of preparation, the physically cross-linked CD-containing hydrogels don't involve the chemical cross-linking agents and chemical solvents, so physical gelatinization and drug encapsulation simultaneously have important research and application value, especially in the aspect of oral administration medicine, ocular delivery system, wound dressing materials, local drug delivery system to treat cancer, etc. 
Table 4. Potential application of physically cross-linked CD-containing hydrogels.

\begin{tabular}{|c|c|c|c|c|c|c|c|}
\hline No. & Drug & $\begin{array}{l}\text { Formation } \\
\text { Materials }\end{array}$ & $\begin{array}{l}\text { Hydrogel } \\
\text { State }\end{array}$ & Type of Cells & Summary & $\begin{array}{c}\text { Potential } \\
\text { Application }\end{array}$ & Ref. \\
\hline 1 & $\begin{array}{c}\text { Berberine } \\
\text { hydrochloride }\end{array}$ & $\begin{array}{c}\beta-C D ; \text { Bacterial } \\
\text { cellulose; }\end{array}$ & $\begin{array}{l}\text { Nano- } \\
\text { particle }\end{array}$ & $\begin{array}{l}\text { S. aureus; } P \text {. } \\
\text { aeruginosa; } E \text {. } \\
\quad \text { coli }\end{array}$ & $\begin{array}{l}\text { The ultra-fine network of bacterial } \\
\text { cellulose resulted in different } \\
\text { release characteristics of berberine } \\
\text { hydrochloride. The drug-loaded } \\
\text { hydrogel had a good antibacterial } \\
\text { effect as revealed by in vitro } \\
\text { experiments. }\end{array}$ & $\begin{array}{l}\text { Oral } \\
\text { administration } \\
\text { medicine }\end{array}$ & [54] \\
\hline 2 & Chlorhexidine & $\begin{array}{c}\beta-\mathrm{CD} ; \mathrm{NaCl} \\
\mathrm{NaHCO}_{3} \\
\mathrm{CaCl}_{2}\end{array}$ & Contact lenses & E. coli & $\begin{array}{l}\beta-C D \text { in eye drops significantly } \\
\text { enhanced the delivery of } \\
\text { chlorhexidine into the cornea. }\end{array}$ & $\begin{array}{l}\text { Ocular } \\
\text { delivery }\end{array}$ & [81] \\
\hline 3 & Coumestrol & $\begin{array}{l}\text { Hydroxypropyl- } \\
\beta-C D ; \\
\text { methylcellu- } \\
\text { lose }\end{array}$ & Not mentioned & Animals & $\begin{array}{l}\text { Hydrogel has high efficacy in } \\
\text { wound healing when compared to } \\
\text { Dersani, with } 50 \% \text { wound healing } \\
\text { achieved within a shorter period } \\
\text { compared to this positive control. }\end{array}$ & $\begin{array}{l}\text { Wound } \\
\text { dressing } \\
\text { materials }\end{array}$ & [53] \\
\hline 4 & Curcumin & $\begin{array}{l}\text { Hydroxypropyl- } \\
\beta \text {-CD; silver } \\
\text { nanoparticles; } \\
\text { bacterial } \\
\text { cellulose }\end{array}$ & Film & $\begin{array}{l}\text { P. aeruginosa; } S \text {. } \\
\text { aureus; } C . \\
\text { aureus; Panc } 1 \text {, } \\
\text { U251, MSTO }\end{array}$ & $\begin{array}{l}\text { The nano-silver particles loaded } \\
\text { into the bacterial cellulose hydrogel } \\
\text { showed high cytocompatibility and } \\
\text { therapeutic effects against three } \\
\text { common wound infection } \\
\text { pathogens. }\end{array}$ & $\begin{array}{l}\text { Wound } \\
\text { dressing } \\
\text { materials }\end{array}$ & [82] \\
\hline 5 & Curcumin & $\begin{array}{c}\beta-C D ; \\
\text { Polyvinyl } \\
\text { alcohol }\end{array}$ & Film & $\begin{array}{l}\text { Glioblastoma } \\
\text { cell line C6; } \\
\text { melanoma cell } \\
\text { line B16F10; } \\
\text { astrocyte cells }\end{array}$ & $\begin{array}{l}\text { The hydrogel controlled the release } \\
\text { of curcumin ( } 48 \mathrm{~h}, 85 \% \text { release). The } \\
\text { polymer membrane had higher } \\
\text { cytotoxicity than curcumin. The } \\
\text { drug-loaded hydrogel showed } \\
\text { prolonged cytotoxic effects (up to } 96 \\
\text { h) at a lower concentration ( } 50 \\
\mu \mathrm{g} / \mathrm{mL} \text { ). }\end{array}$ & $\begin{array}{l}\text { Local drug } \\
\text { delivery } \\
\text { system to treat } \\
\text { cancer }\end{array}$ & [83] \\
\hline 6 & Curcumin & $\begin{array}{l}\text { 2- } \\
\text { hydroxypropyl- } \\
\beta \text {-CD; sodium } \\
\text { alginate; } \\
\text { chitosan }\end{array}$ & Film & $\begin{array}{l}\text { E. coli; } S \text {. } \\
\text { aureus; NCTC } \\
\text { clone } 929 \text { cells; } \\
\text { NHDF cells }\end{array}$ & $\begin{array}{l}\text { High concentration of crosslinking } \\
\text { agent concentration improved the } \\
\text { mechanical properties of the } \\
\text { hydrogel and decreased the } \\
\text { hygroscopicity, water swelling, and } \\
\text { weight loss. In addition, hydrogel } \\
\text { showed a slow-release effect ( } \mathrm{t}>50 \\
\text { h). Curcumin-loaded double-layer } \\
\text { hydrogel effectively treated E. coli } \\
\text { and S. aureus. The double-layer } \\
\text { hydrogel was not toxic to NCTC } \\
\text { clone } 929 \text { cells and normal human } \\
\text { dermal fibroblasts. }\end{array}$ & $\begin{array}{l}\text { Wound } \\
\text { dressing } \\
\text { materials }\end{array}$ & [48] \\
\hline 7 & Gallic acid & $\begin{array}{l}\text { Hydroxypropyl- } \\
\beta-C D ; \text { bacterial } \\
\text { cellulose; poly } \\
\text { (vinyl alcohol) }\end{array}$ & Not mentioned & Not mentioned & $\begin{array}{l}\text { The swelling properties during } \\
\text { encapsulation were inferior. The } \\
\text { release profile of the complex was } \\
\text { slower compared with gallic acid. }\end{array}$ & $\begin{array}{l}\text { Pharmaceutical } \\
\text { and cosmetic } \\
\text { products }\end{array}$ & [55] \\
\hline 8 & $\begin{array}{l}\text { Honey bee } \\
\text { propolis } \\
\text { extract }\end{array}$ & $\begin{array}{c}\beta-C D ; \\
\kappa \text {-Carrageenan }\end{array}$ & Not mentioned & $\begin{array}{l}\text { S. aureus; } \\
\text { P. aeruginosa; } \\
\text { Aspergillus } \\
\text { Flavus; Candida } \\
\text { albicans }\end{array}$ & $\begin{array}{l}\text { Higher active compound } \\
\text { concentration ensures sustained } \\
\text { in vitro release. }\end{array}$ & $\begin{array}{l}\text { Wound } \\
\text { dressing }\end{array}$ & [80] \\
\hline 9 & $\begin{array}{l}\text { Levofloxacin; } \\
\text { methotrexate }\end{array}$ & $\begin{array}{l}\text { Hydroxypropyl- } \\
\beta-C D ; \text { xanthan } \\
\text { gum }\end{array}$ & Film & E. coli; S. aureus & $\begin{array}{c}\text { The hydrogel loaded with the } \\
\text { methotrexate showed a } \\
\text { well-controlled release profile }(\mathrm{t}> \\
600 \text { min). The hydrogel loaded with } \\
\text { levofloxacin had a good } \\
\text { antibacterial effect. }\end{array}$ & $\begin{array}{l}\text { Drug delivery } \\
\text { system }\end{array}$ & [57] \\
\hline
\end{tabular}


Table 4. Cont.

\begin{tabular}{|c|c|c|c|c|c|c|c|}
\hline No. & Drug & $\begin{array}{l}\text { Formation } \\
\text { Materials }\end{array}$ & $\begin{array}{l}\text { Hydrogel } \\
\text { State }\end{array}$ & Type of Cells & Summary & $\begin{array}{c}\text { Potential } \\
\text { Application }\end{array}$ & Ref. \\
\hline 10 & Red thyme oil & $\begin{array}{c}\gamma-\mathrm{CD} ; \\
\text { polyvinyl } \\
\text { alcohol; } \\
\text { chitosan; } \\
\text { clinoptilolite }\end{array}$ & Film & L929 cells & $\begin{array}{l}\text { Hydrogels with clinoptilolite } \\
\text { contained characteristics such as } \\
\text { compressed structure, improved } \\
\text { mechanical properties, decreased } \\
\text { swelling values, and reduced } \\
\text { release rate of the drug. In addition, } \\
\text { prepared hydrogels were low-toxic } \\
\text { based on MTT assay. }\end{array}$ & $\begin{array}{c}\text { Drug delivery } \\
\text { systems and } \\
\text { wound } \\
\text { dressings }\end{array}$ & [84] \\
\hline 11 & Thyme oil & $\begin{array}{c}\text { Methyl- } \beta-C D ; \\
\text { hydroxypropyl- } \\
\beta-C D ; \gamma-C D ; \\
\text { chitosan; } \\
\text { polyvinyl } \\
\text { alcohol }\end{array}$ & Film & E. coli; S. aureus & $\begin{array}{l}\text { The water vapor transmission rate } \\
\text { of the hydrogel was appropriate for } \\
\text { application in wound dressing. The } \\
\text { swelling degree of hydrogel loaded } \\
\text { with thyme oil varied with the pH. } \\
\text { The hydrogels containing } \gamma \text {-CD had } \\
\text { good antibacterial activity. }\end{array}$ & $\begin{array}{l}\text { Wound } \\
\text { dressings }\end{array}$ & $\begin{array}{l}{[49,} \\
85]\end{array}$ \\
\hline
\end{tabular}

Sajeesh et al. used chitosan, methacrylic acid, and polyethylene glycol to prepare hydrogels, and then added insulin-loaded methyl- $\beta-C D$ into the hydrogels [86]. Final hydrogel particles were formed through the interaction between $C D$ and the hydrogel matrix. The encapsulation efficiency of the inclusion compound and insulin encapsulated by hydrogel microparticles were evaluated. No significant differences were observed in the encapsulation efficiency of the two systems. Insulin concentrations of 0.5 and $1 \mathrm{mg} / \mathrm{mL}$ showed an encapsulation efficiency of the inclusion compound preparation of $87 \%$ and $82 \%$, respectively. The efficiency of the non-encapsulated system was $90 \%$ and $85 \%$ for insulin concentration at 0.5 and $1 \mathrm{mg} / \mathrm{mL}$, respectively. In addition, in vitro drug release experiment showed that the inclusion compound encapsulated by the hydrogel exhibited $\mathrm{pH}$ responsiveness. At $\mathrm{pH}=1.2$ and 7.4, the amount of insulin released under more acidic conditions was significantly lower compared with that under neutral conditions over the same period. The effect of oral delivery of insulin by CD hydrogel inclusion compound microparticles was studied using streptozotocin-induced diabetic rats. The experimental results exhibited that insulin loading, and release characteristics of the hydrogel matrix were not affected by the complexation of $\mathrm{CD}$. In addition, $\mathrm{CD}$ compound insulin coated by hydrogel particles effectively reduced blood sugar levels in diabetic animals.

To deliver oral hypoglycemic drugs into the body, Okubo et al. employed the hostguest interaction between hydrophobically modified hydroxypropyl methylcellulose and $\mathrm{CD}$ to develop and prepare heat-responsive injectable drug sustained-release hydrogel. The hydrogel was prepared by mixing the $\mathrm{CD}$ inclusion compound containing insulin with cellulose. Due to the interaction between the stearyl group of cellulose and the $\beta$-CD cavity, the hydrogel underwent a thermal gelation reaction near the human body temperature. The newly prepared hydrogel was effective for up to $24 \mathrm{~h}$ after subcutaneous administration of mice. Notably, pharmacokinetic experiment results showed that the hydrogel released insulin which reduced the blood sugar levels [87].

Drugs can be delivered into the human intestinal tract through oral administration to achieve high efficacy [88]. The solubility of berberine hydrochloride could be enhanced by $\beta$-CD $\left(25^{\circ} \mathrm{C}, 11.41 \mathrm{mM}\right)$. CD-loaded berberine hydrochloride-containing bacterial cellulose hydrogel was prepared by physical adsorption, and its drug loading ( $34 \%)$ was higher compared with that of hydrogels prepared without CD (17.2\%). In vitro, drug release experiments revealed that the hydrogel achieved sustained drug release $(t>70 h)$ under different $\mathrm{pH}$ conditions $(\mathrm{pH}=1.2,6.8$, and 12.1) of the gastrointestinal fluid. In vitro antibacterial experiments exhibited that hydrogels had better antibacterial effects (E. coli, $S$. aureus, and P. aeruginosa), thus laying the foundation for oral drug delivery [54].

To speed up the healing of wounds on the skin surface and prevent bacterial infections, some wound dressings are prepared through the physical synthesis method $[89,90]$. Sodium alginate and chitosan are mixed to form a hydrogel matrix, and then $\beta-C D$ inclusion 
compound containing curcumin is added as an active ingredient. It is reported that sodium alginate and chitosan adsorb each other through electrostatic interaction. The mechanical properties of hydrogel materials are significantly improved by an increase in calcium chloride content. In the active ingredient release study, the hydrogel displayed a sustained release effect $(t>48 \mathrm{~h})$, which was not affected by the addition of calcium chloride. The curcumin-loaded hydrogel showed a good inhibitory effect on the growth of E. coli $(73.95 \%)$ and S. aureus $(71.59 \%)$. Toxicity studies displayed that the hydrogel was non-toxic to NCTC clone 929 cells and normal human dermal fibroblasts [48]. A similar study used hydroxypropyl- $\beta-C D$ as a drug carrier for loading curcumin and added silver nanoparticles with antibacterial activity to the hydrogels. These hydrogels showed broadspectrum antibacterial activity and antioxidant properties and can be used for wound dressing. In addition, the hydrogels showed good cell compatibility with different cell lines, including Panc 1 (human pancreatic ductal adenocarcinoma), U251 (Human brain glioma U251 cell line), and MSTO (human mesothelioma). Its high moisture content and good transparency further promote its application potential for the treatment of chronic wounds [82].

Because most people do not pay much attention to hygiene, the risk of pathogenic microorganisms coming into contact with the body is high. The eye, an organ that is directly in contact with the external environment, often suffers from keratitis due to infection by pathogens [91]. If keratitis is left untreated, it may cause permanent vision damage. Eye drops are the preferred method of drug delivery for the timely treatment of infections [92]. However, when eyes are stimulated by the outside environment, the number of blinks and secretion of tears will increase, thus most of the eye drops do not reach the infected areas. Therefore, the frequency of administration of eye drops is increased to increase efficacy. Hewitt et al. explored the possibility of adding drugs to contact lenses. They selected pig eyes as the research object and prepared a hydrogel with $\beta$-CD loaded with chlorhexidine. Antibacterial analysis showed that the drug-containing contact lenses delivered a high amount of chlorhexidine to the cornea within $24 \mathrm{~h}$. Although the contact lens loaded with chlorhexidine $\beta-\mathrm{CD}$ failed to improve the drug delivery effect, it was able to deliver the drug to the cornea. In addition, $\beta$-CD hindered drug release in the hydrogel matrix. Continuous irrigation with simulated tear fluid can significantly reduce the amount of drug delivered to the cornea. Chlorhexidine retains antibacterial activity in all methods of administration. The hydrogel contact lens injected with chlorhexidine showed a significantly higher effect on the cornea, whether it was used multiple times or once compared with eye drops. Therefore, this method can be used to reduce the number of administrations thus improving patient tolerance degree [81].

\subsection{Chemically Cross-Linked CD-Containing Hydrogels}

The chemically cross-linked CD-containing hydrogels are not easily degraded in the external environment, thus reducing the number of hydrogels used during the application, ultimately mitigating side effects by the hydrogel drug delivery system (Table 5). Chemical methods can be used to prepare chemically cross-linked CD-containing hydrogels which possess much higher stability than the physically cross-linked CD-containing hydrogels, comparatively speaking. Therefore, the application scope of chemically cross-linked CDcontaining hydrogels has been extended to some extent by changing the properties of hydrogels through different chemical reactions., especially in the aspect of injectable nanocarriers, cancer therapy, transdermal drug delivery, tissue engineering, regenerative medicine, wound healing, oral drug delivery, etc. 
Table 5. Potential application of chemically cross-linked CD-containing hydrogels.

\begin{tabular}{|c|c|c|c|c|c|c|c|}
\hline No. & Drug & $\begin{array}{c}\text { Formation } \\
\text { Materials }\end{array}$ & $\begin{array}{c}\text { Hydrogel } \\
\text { State }\end{array}$ & Types of Cell & Summary & $\begin{array}{c}\text { Potential } \\
\text { Application }\end{array}$ & Ref. \\
\hline 1 & 5-Fluorouracil & $\begin{array}{l}\beta-\mathrm{CD} ; \mathrm{N}- \\
\text { vinylcaprolactam; } \\
\quad N \\
N^{\prime} \text {-methylene } \\
\text { bisacrylamide }\end{array}$ & Nanogel & $\begin{array}{l}\text { Human colon } \\
\text { cancer cell } \\
\text { lines (HCT } \\
\text { 116); MRC-5 } \\
\text { normal cells }\end{array}$ & $\begin{array}{l}\text { The hydrogel had the best drug } \\
\text { loading ( } 659.7 \mathrm{mg} / \mathrm{g} \text { ) after } \\
\text { controlling the feeding ratio. The } \\
\text { drug release curve showed that the } \\
\text { hydrogel could continue to release } \\
\text { drugs for up to } 30 \mathrm{~h} \text {; especially in } \\
\text { the intestinal juice with pH = 7.4, } \\
\text { the 5-fluorouracil drug molecules } \\
\text { contained therein were not } \\
\text { completely released; and the } \\
\text { maximum release rate was } 68 \% \text {. }\end{array}$ & $\begin{array}{l}\text { Implantable } \\
\text { hydrogels }\end{array}$ & [93] \\
\hline 2 & Coumarin & $\begin{array}{l}\beta-\mathrm{CD} \text {; alginate; } \\
\text { calcium } \\
\text { homopoly-L- } \\
\text { guluronate }\end{array}$ & $\begin{array}{c}\text { Supramolecular } \\
\text { hydrogel }\end{array}$ & $\begin{array}{l}\text { RAW } 264.7 \\
\text { cells; T. cruzi } \\
\text { cells }\end{array}$ & $\begin{array}{l}\text { The lowest release of substituted } \\
\text { amidocoumarins from the } \\
\text { hydrogels occurred at } \mathrm{pH}=1.2 \\
\text { whereas the maximum release }(34 \%) \\
\text { was observed at pH } 8.0 .\end{array}$ & Biomedicine & [94] \\
\hline 3 & Curcumin & $\beta-C D ;$ epiclon & Nanosponge & $\begin{array}{l}\text { Non- } \\
\text { tumorigenic } \\
\text { human breast; } \\
\text { invasive } \\
\text { mouse } \\
\text { breast cell lines } \\
\text { (4T1) }\end{array}$ & $\begin{array}{l}\text { The high degree of cross-linking led } \\
\text { to the formation of mesoporous } \\
\text { having high specific surface area } \\
\text { and high loading capacity. } \\
\text { Nanosponge showed no toxicity } \\
\text { against MCF 10A and } 4 \mathrm{~T} 1 \text { cells as } \\
\text { normal and cancerous cells, } \\
\text { respectively. }\end{array}$ & Cancer therapy & [95] \\
\hline 4 & Curcumin & $\begin{array}{l}\text { Carboxymethyl- } \\
\beta-C D ; \text { gelatin; } \\
\text { methacrylic } \\
\text { anhydride }\end{array}$ & $\begin{array}{l}\text { Microneedle } \\
\text { arrays }\end{array}$ & $\begin{array}{c}\text { B16F10 } \\
\text { melanoma cell }\end{array}$ & $\begin{array}{l}\text { The inclusion complex of curcumin } \\
\text { maintained } 90 \% \text { of the initial } \\
\text { concentration. Besides, the hydrogel } \\
\text { could enhance the drug loading and } \\
\text { adjust release. In vivo study } \\
\text { showed that hydrogel had good } \\
\text { biocompatibility and degradability. }\end{array}$ & $\begin{array}{l}\text { Transdermal } \\
\text { drug delivery }\end{array}$ & [96] \\
\hline 5 & Dexamethasone & $\begin{array}{l}\beta-C D ; \text { low-acyl } \\
\text { gellan gum; } \\
\text { EDC }\end{array}$ & $\begin{array}{l}\text { Injectable } \\
\text { hydrogel }\end{array}$ & $\begin{array}{c}\mathrm{NIH} / 3 \mathrm{~T} 3 \\
\text { mouse embryo } \\
\text { fibroblast }\end{array}$ & $\begin{array}{l}\text { After drug loading, the gel-forming } \\
\text { temperature of the modified } \\
\text { hydrogel was reduced and the } \\
\text { mechanical properties are improved. } \\
\text { Hydrogel had a high affinity and } \\
\text { release rate for drugs. In vivo } \\
\text { studies had shown that the } \\
\text { drug-loaded hydrogel improved the } \\
\text { anti-inflammatory response. }\end{array}$ & $\begin{array}{l}\text { Tissue } \\
\text { engineering } \\
\text { and } \\
\text { regenerative } \\
\text { medicine }\end{array}$ & [52] \\
\hline 6 & Dexamethasone & $\begin{array}{l}\beta-C D ; \text { sodium } \\
\text { hyaluronate }\end{array}$ & $\begin{array}{l}\text { Delivery } \\
\text { hydrogel }\end{array}$ & 3T3 cells & $\begin{array}{l}\text { The novel hydrogels significantly } \\
\text { improved the therapeutic effect of } \\
\text { dexamethasone in burn wound } \\
\text { healing. }\end{array}$ & Wound healing & {$[58]$} \\
\hline 7 & Dexibuprofen & $\begin{array}{l}\beta-C D ; \text { acrylic } \\
\text { acid; } \\
\text { methylene } \\
\text { bisacrylamide }\end{array}$ & Nanosponges & Not mentioned & $\begin{array}{l}\text { The solubility of ibuprofen in the } \\
\text { hydrogel was increased } 6.3 \text { times. } \\
\text { In vitro release experiments } \\
\text { demonstrated that the drug release } \\
\text { rate of } \beta \text {-CD nanosponges reached } \\
89 \% \text { within } 30 \text { min under the } \\
\text { condition of } \mathrm{pH}=6.8 \text {. }\end{array}$ & $\begin{array}{l}\text { Oral } \\
\text { administration } \\
\text { of lipophilic } \\
\text { drugs }\end{array}$ & [97] \\
\hline 8 & $\begin{array}{l}\text { Diclofenac } \\
\text { sodium }\end{array}$ & $\begin{array}{c}\beta-C D ; \text { sodium } \\
\text { hyaluronan; } \\
\text { EDC; }\end{array}$ & $\begin{array}{l}\text { Contact lens } \\
\text { materials }\end{array}$ & $\begin{array}{l}\text { S. aureus; 3T3 } \\
\text { fibroblasts }\end{array}$ & $\begin{array}{l}\text { The hydrogel not only reduced the } \\
\text { adsorption of tearing proteins due } \\
\text { to electrostatic mutual repulsion but } \\
\text { also improved encapsulation } \\
\text { capacity and sustainable release of } \\
\text { diclofenac }(\mathrm{t}>72 \mathrm{~h} \text { ). In vitro cell } \\
\text { viability analysis displayed that all } \\
\text { hydrogels were non-toxic to 3T3 } \\
\text { mouse fibroblasts. }\end{array}$ & $\begin{array}{l}\text { Ophthalmic } \\
\text { diseases }\end{array}$ & [66] \\
\hline
\end{tabular}


Table 5. Cont

\begin{tabular}{|c|c|c|c|c|c|c|c|}
\hline No. & Drug & $\begin{array}{l}\text { Formation } \\
\text { Materials }\end{array}$ & $\begin{array}{l}\text { Hydrogel } \\
\text { State }\end{array}$ & Types of Cell & Summary & $\begin{array}{c}\text { Potential } \\
\text { Application }\end{array}$ & Ref. \\
\hline 9 & Doxorubicin & $\begin{array}{l}\beta \text {-CD; 2-ethyl- } \\
\text { 2-oxazoline; } \\
\text { aminopropyl- } \\
\text { triethoxy } \\
\text { silane; } \\
\mathrm{FeCl}_{2} \cdot 4 \mathrm{H}_{2} \mathrm{O} ; \\
\mathrm{FeCl}_{3} \cdot 6 \mathrm{H}_{2} \mathrm{O}\end{array}$ & $\begin{array}{c}\text { Magnetic } \\
\text { nanohydrogel }\end{array}$ & MCF7 cells & $\begin{array}{l}\text { The magnetic nanohydrogel had a } \\
\text { good drug loading rate }(74 \%) \text { and } \\
\text { encapsulation rate }(81 \%) \text {. Under } \\
\text { acidic conditions }(\mathrm{pH}=5.3) \text {, adding } \\
\text { a small amount of } \mathrm{GSH}(10 \mathrm{mM}) \\
\text { increased the release value }(89.21 \%) \text {. } \\
\text { The magnetic nanohydrogel had } \\
\text { good cell compatibility even at high } \\
\text { concentrations }(10 \mathrm{mg} / \mathrm{mL}) .\end{array}$ & $\begin{array}{l}\text { Implantable } \\
\text { hydrogels }\end{array}$ & [98] \\
\hline 10 & Doxorubicin & $\beta-C D ;$ agarose & $\begin{array}{l}\text { Injectable } \\
\text { hydrogel }\end{array}$ & $\begin{array}{l}\text { Human } \\
\text { embryonic } \\
\text { kidney } 239 \\
\text { cells; HeLa } \\
\quad \text { cells }\end{array}$ & $\begin{array}{l}\text { The hydrogel was able to easily and } \\
\text { uniformly load a drug at } 30^{\circ} \mathrm{C} \text {. The } \\
\text { drug-loaded hydrogel maintained } \\
\text { the drug's anti-cancer activity. In } \\
\text { addition, the hydrogels did not } \\
\text { exhibit toxicity toward the HEK-293 } \\
\text { and HeLa cells. }\end{array}$ & $\begin{array}{l}\text { Injectable } \\
\text { hydrogel }\end{array}$ & [59] \\
\hline 11 & Doxorubicin & $\begin{array}{l}\beta-C D ; \\
\text { hyaluronic } \\
\text { acid; bis(4- } \\
\text { nitrophenyl) } \\
\text { carbonate }\end{array}$ & $\begin{array}{l}\text { Injectable } \\
\text { hydrogel }\end{array}$ & $\begin{array}{l}\text { Human } \\
\text { colorectal } \\
\text { cancer cells } \\
\text { HCT-116 }\end{array}$ & $\begin{array}{l}\text { Rheological tests showed that this } \\
\text { hydrogel could be easily prepared } \\
\text { and used on a schedule compatible } \\
\text { with normal operating room } \\
\text { procedures. In vitro experiments } \\
\text { showed that the unique physical } \\
\text { and chemical properties of the } \\
\text { hydrogel ensured the sustained } \\
\text { release of anticancer drugs ( } \mathrm{t}>32 \mathrm{~d} \text { ) } \\
\text { and prevented the growth of } \\
\text { colorectal cancer micelles under 3D } \\
\text { culture conditions. }\end{array}$ & $\begin{array}{l}\text { Device for } \\
\text { localized } \\
\text { chemotherapy } \\
\text { of solid tumors }\end{array}$ & [99] \\
\hline 12 & $\begin{array}{l}\text { Doxorubicin; } \\
\text { curcumin }\end{array}$ & $\begin{array}{c}\beta-C D ; \\
\text { multiwalled } \\
\text { carbon } \\
\text { nanotubes; } \\
\text { maleic } \\
\text { anhydride; } \\
\text { folic acid; hex- } \\
\text { amethylene } \\
\text { diisocyanate }\end{array}$ & Nanocarrier & Not mentioned & $\begin{array}{l}\text { This injectable hydrogel exhibited } \\
\mathrm{pH} / \text { thermo response and exerted a } \\
\text { deleterious effect on the tumor. A } \\
\text { sustained release of the two drugs } \\
\text { was observed over a period of } 30 \mathrm{~h} \text {. } \\
\text { The release rate of doxorubicin } \\
\text { reached } 90 \% \text { under tumor } \\
\text { microenvironmental conditions, } \\
\text { and the release rate of curcumin } \\
\text { reached } 85 \% \text { under high } \\
\text { temperature and physiological pH } \\
\text { conditions. }\end{array}$ & $\begin{array}{c}\text { Injectable } \\
\text { nanocarriers }\end{array}$ & [100] \\
\hline 13 & Doxorubicin & $\begin{array}{l}\beta-C D ; \text { tetronic; } \\
\text { adamantane }\end{array}$ & $\begin{array}{c}\text { Injectable } \\
\text { shear-thinning } \\
\text { hydrogels }\end{array}$ & HeLa cell & $\begin{array}{l}\text { The hydrogels showed } \\
\text { shear-thinning behaviors, rapid } \\
\text { recovery properties, pH-responsive } \\
\text { properties, and long-term release of } \\
\text { the hydrophobic drug. }\end{array}$ & $\begin{array}{l}\text { Embolic } \\
\text { material }\end{array}$ & [101] \\
\hline 14 & Insulin & $\begin{array}{l}\text { Carboxymethyl } \\
\beta-C D ; \\
\text { carboxymethyl } \\
\text { chitosan }\end{array}$ & Microparticles & Caco- 2 cells & $\begin{array}{l}\text { The insulin was loaded into the } \\
\text { hydrogel, and the results of the } \\
\text { drug release experiment found that } \\
\text { the insulin was successfully } \\
\text { retained in the stomach } \\
\text { environment and slowly released } \\
\text { after passing through the intestine. } \\
\text { In vitro studies had shown that the } \\
\text { hydrogel particles exhibited } \\
\text { non-cytotoxicity and were mainly } \\
\text { transported in the Caco-2 cell } \\
\text { monolayer through paracellular } \\
\text { pathways. }\end{array}$ & $\begin{array}{l}\text { Oral drug } \\
\text { delivery }\end{array}$ & [102] \\
\hline
\end{tabular}


Table 5. Cont

\begin{tabular}{|c|c|c|c|c|c|c|c|}
\hline No. & Drug & $\begin{array}{c}\text { Formation } \\
\text { Materials }\end{array}$ & $\begin{array}{l}\text { Hydrogel } \\
\text { State }\end{array}$ & Types of Cell & Summary & $\begin{array}{l}\text { Potential } \\
\text { Application }\end{array}$ & Ref. \\
\hline 15 & Vitamin E & $\begin{array}{l}\beta-C D ; \text { soy } \\
\text { soluble } \\
\text { polysaccha- } \\
\text { rides; } \\
\text { galacturonic } \\
\text { acid }\end{array}$ & $\begin{array}{l}\text { Core-shell bio- } \\
\text { nanomaterials } \\
\text { hydrogel }\end{array}$ & Not mentioned & $\begin{array}{l}\text { The hydrogel exhibited significant } \\
\text { swelling adsorption and sustained } \\
\text { release }(t>230 \mathrm{~h} \text { ) for the release of } \\
\text { vitamin } \mathrm{E} \text { in vitro. The } \\
\text { encapsulation efficiency and drug } \\
\text { loadings were } 79.10 \% \text { and } 16.04 \% \text {, } \\
\text { respectively. In addition, after oral } \\
\text { administration of the vitamin } \\
\text { E-loaded hydrogel in rats, the } \\
\text { vitamin } \mathrm{E} \text { level in the plasma } \\
\text { continued to increase within } 12 \mathrm{~h} \text {. }\end{array}$ & $\begin{array}{l}\text { Oral drug } \\
\text { carrier }\end{array}$ & [56] \\
\hline
\end{tabular}

Several studies are currently exploring controlled drug delivery systems based on CD-containing hydrogels [103-106]. Xia et al. used new hesperidin-copper (II) (NH-Cu (II)) as the model drug, then added it into a hydrogel composed of carboxymethyl cellulose $(\mathrm{CMC})$, cellulose nanocrystals $(\mathrm{CNC})$, and hydroxypropyl- $\beta-\mathrm{CD}$. Citric acid was used as a cross-linking agent to prepare a natural hydrogel film which exhibited controllable swelling behavior. The different dynamic behaviors of $\mathrm{NH}-\mathrm{Cu}$ (II) in the hydrogel film were then explored. Drug release studies showed that the hydrogel had a sustained release effect at different temperatures. Furthermore, it had different swelling behavior under different $\mathrm{pH}$ and different ion concentrations. The swelling kinetics followed the Fick diffusion and Schott second-order kinetic model. In addition, the addition of CNC into hydrogel film changed the mechanical properties, thermal stability at high temperatures, swelling rate, salt sensitivity, and $\mathrm{pH}$ sensitivity of the hydrogel film in different solutions. Moreover, $\mathrm{CNC}$ greatly improved the loading and encapsulation efficiency of the hydrogel film. The addition of $4 \% \mathrm{CNC}$ showed an optimal loading efficiency of $753.75 \mathrm{mg} / \mathrm{g}$ and a cumulative release rate of $85.08 \%$. The hydrogel membrane showed good cell compatibility and was non-cytotoxic, thus it can be used as a potential drug delivery and controlled release system for wound dressing [63].

Targeted delivery of anti-cancer drugs is one of the most effective treatment methods for tumors [107]. Therefore, direct injection of the drug-containing hydrogel at the tumor area to maximize drug concentration improves the efficacy of the drug. Hyaluronic acid derivative and functionalized $\mathrm{CD}$ can be linked by a covalent bond to prepare an injectable hydrogel, and doxorubicin is successfully loaded in the CD cavity. In vitro release experiments of the drug-loaded hydrogels displayed a sustained-release effect. In this case, the hydrophobic interaction between doxorubicin and $\mathrm{CD}$ cavity resulted in drug retention in the hydrogel, thereby slowing its diffusion through the three-dimensional network. Notably, after 32 days of incubation, only $50 \%$ of the drug load was released in the medium without a significant burst effect. In addition, the hydrogel reduced the size of solid tumors in mice. Moreover, histological analysis of the heart of treated mice displayed showed no cardiotoxicity after treatment of the tumor with the drug-loaded hydrogel. These results implied that this drug-loaded hydrogel is an effective biomedical device to locally treat unresectable solid tumors or for preventing regeneration of residual tumors and inhibiting disease recurrence [99].

Subcutaneous administration of drugs has some side effects. For example, when treating diabetes, people prefer injecting insulin under the skin. However, daily insulin injection is associated with adverse effects, such as hypoglycemia, allergies, and peripheral hyperinsulinemia [102]. Therefore, an oral insulin delivery system can be used to avoid these side effects. A previous study reports oral hydrogen comprising CD and chitosan as raw materials and a water-soluble carbodiimide as cross-linking agent. SEM (scanning electron microscope), FTIR (Fourier transform infrared spectroscopy), XRD (X-Ray diffraction), and swelling experiments indicated the hydrogel had a porous structure. Insulin release behavior was shown to be triggered by in vitro $\mathrm{pH}$. Notably, insulin was successfully retained 
in the stomach environment and slowly released after passing through the intestine. The stability of insulin secondary structure was studied by circular dichroism and fluorescence spectrophotometry. Analysis experiment revealed no significant difference in secondary structure between native insulin and released insulin. Furthermore, the hydrogel particles exhibit non-cytotoxicity and were mainly transported in the Caco-2 cell monolayer through paracellular pathways. Different insulin-loaded hydrogel microparticles were applied to diabetic mice to evaluate the effectiveness of hydrogel sustained-release microparticles in delivering insulin in the body. Insulin-loaded hydrogel particles significantly and continuously (6-12 h) reduced blood sugar levels in diabetic mice compared with subcutaneous injection. In summary, these findings indicate that hydrogel is a promising oral drug carrier to achieve sustained release [102].

Previous studies explored the use of chemically cross-linked hydrogels and compared them with physically cross-linked hydrogels for the treatment of eye diseases [108]. Cyclosporine is a commonly used drug for the treatment of various immune-mediated ocular surface diseases [109]. However, the poor water solubility of cyclosporine limits its application. Only two topical formulations of cyclosporine have been approved for the treatment of dry eye syndrome, Resis (Allergan, USA). An anionic emulsion $(0.5 \mathrm{mg} / \mathrm{mL}$ cyclosporine) was approved by the FDA in 2002, and Ikervis was recently approved in Europe (Santen, Tampere, Finland), a cationic nanoemulsion containing $1 \mathrm{mg} / \mathrm{mL}$ cyclosporine [110-112]. Sodium hyaluronate and hydroxypropyl- $\beta-\mathrm{CD}$ are used as raw materials to prepare a chemically cross-linked hydrogel. Cyclosporin is loaded into the hydrogel by dipping to avoid degradation of cyclosporin during the cross-linking reaction. Interestingly, changing the weight ratio of the raw materials in the hydrogel adjusts the swelling and the rate of drug release. The swelling plays a key role in the feasibility of the drug penetrating through the sclera and accumulating into the eye tissue. In vitro drug release, experiments show that the hydrogel has a release time of up to $8 \mathrm{~h}$. Therefore, chemically cross-linked hydrogels are effective systems for drug release to the ocular surface, however, the effectiveness should be confirmed in preclinical studies [67].

The polymerization system of the hydrogel obtained by $\mathrm{CD}$ polymerization and swelling has very few pores. Khalid et al. used $\beta-C D$, acrylic acid, and acrylamide to prepare $\beta-C D$ nanosponges for loading dexibuprofen. Water solubility experiments showed that the water solubility of dexibuprofen was increased by 6.3 times after loading it to the hydrogel. The particle size of this material was $275.1 \pm 28.5 \mathrm{~nm}$. The swelling index of the nanosponge under weakly acidic conditions $(\mathrm{pH}=6.8)$ was 3 , and up to $89 \%$ dexibuprofen was successfully released within $30 \mathrm{~min}$ under this condition. An acute oral toxicity study using rats showed no toxicity-related conditions, death, adverse clinical symptoms and had no toxicological changes in hematology, clinical biochemistry, and histology. Therefore, the $\beta-C D$ nanosponges prepared through the optimized condensation method may be superior compared with other $\beta-C D$ nanoformulations, thus they improve oral administration of lipophilic drugs such as dexibuprofen [97].

\section{Simulated Degradation Behavior for CD-Containing Hydrogels}

The degradation process of hydrogel is one of the key indicators of its safety, and it is also the basis for studying in vivo decomposition of the hydrogel [113-115]. In vitro degradation behavior is studied through changes of the hydrogel under conditions such as simulated body fluids, different types of biological enzymes, and different acids and bases (Figure 2). 


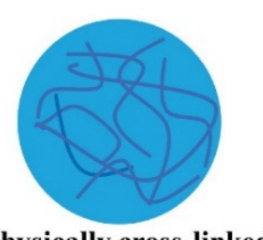

Physically cross-linked CD-containing hydrogels

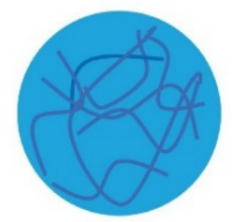

Chemically cross-linked CD-containing hydrogels
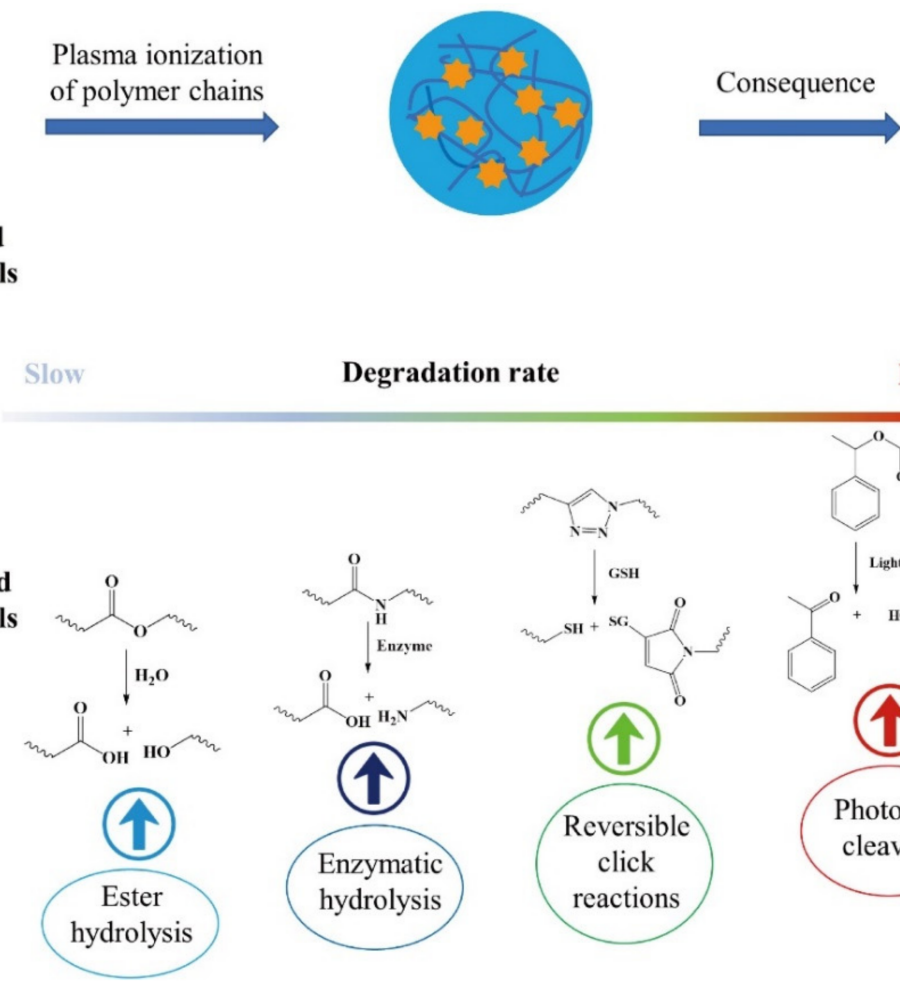

Plasma ionization
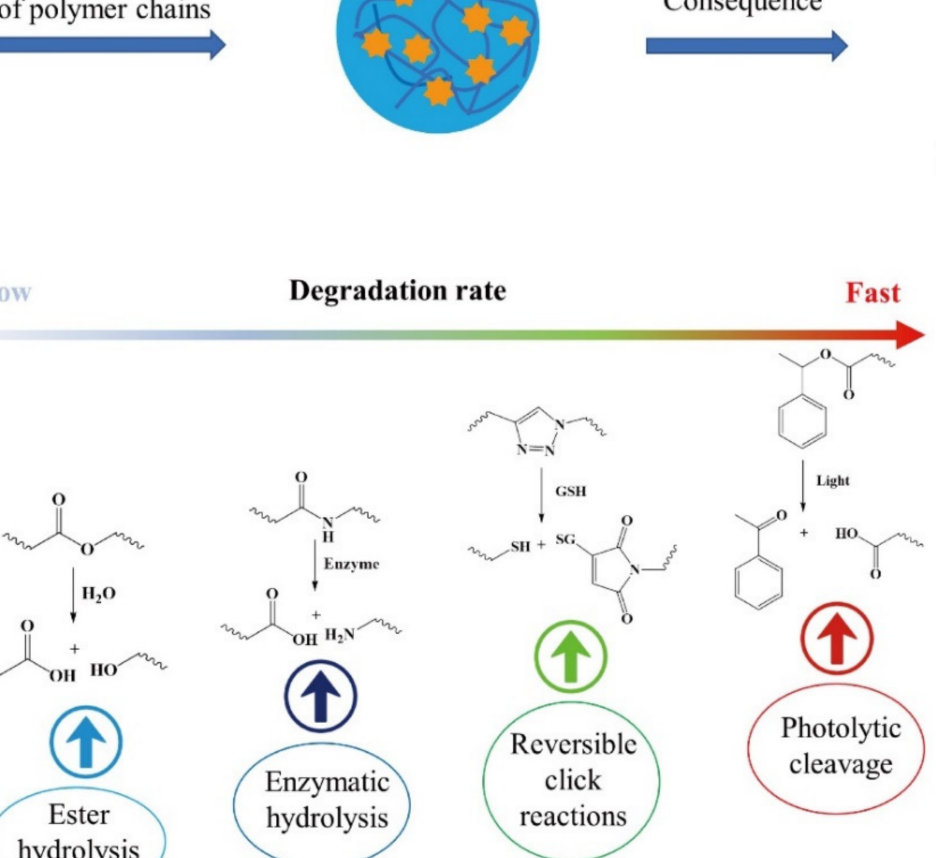

Figure 2. Simulated degradation behavior for CD-containing hydrogels.

A previous study placed CD-based hydrogel loaded with gellan gum in a phosphate buffer solution ( $\mathrm{pH}=7.4)$, and the weight loss of the hydrogel was measured at 1, 7, 14, 21 days. Analysis showed that the weight loss rate of the hydrogel was low with the content of $C D$ and that the weight loss rate of the modified hydrogel was higher compared with hydrogels without $C D$. This phenomenon can be attributed to the reduction of crosslinking sites in the modified hydrogel that lead to more unassociated chains in the gel network. In addition, hydrogels without $\mathrm{CD}$ had a slower degradation rate compared with those with $C D$, implying that the presence of $C D$ in the matrix may increase the decomposition rate of the hydrogel [52]. Exposure of different hydrogels to the external environment, such as a phosphate buffer $(\mathrm{pH}=7.4)$, showed that hydrogels with large cross-linking concentrations required longer hydrolysis time. Unfortunately, the higher cross-linking degree of the hydrogels caused more resistance to degradation in collagenase solution in PBS buffer. The cross-linking could limit the accessibility of enzymes to the cleavage sites of the hydrogels, and prevent the enzymes from penetrating the bulk of the material [116]. The degradation mechanism of these hydrogels mainly resulted from the breaking of cross-linking sites, ester bonds, hydrazone bonds, or steric hindrance through chemical hydrolysis. The polymer backbone was then hydrolyzed and broken into lower molecular weight and soluble fragments [117-123].

Degradation of hydrogel under pure water conditions was simulated, and the degradation rate of gallic acid-loaded hydrogel was explored to determine the environmental safety of bio-based hydrogels. Analysis showed that degradation of the hydrogel was relatively fast in the initial stages, however, it remained stable within 8-360 h. This degradation behavior can be attributed to the effect of water penetration in the bacterial cellulose hydrogel network which resulted in the good degradation behavior of hydrogel. Moreover, the aromatic ring (the presence of gallic acid and CD), slightly slows the degradation ability of the hydrogel. The aromatic ring may delay the degradation of the hydrogel [55].

The ability of hydrogels to degrade in the presence of organisms is important for drug release. A previous study evaluated the degradation of CD-based hydrogel using Penicillium, Aspergillus niger, and mushroom. Analysis showed that the gel changed to a liquid after six days of degradation. The degradation rate of the hydrogel increased gradually in 
Penicillium. In Penicillium, the degradation rate was $6.11 \%$ after three days, whereas after 21 days the degradation rate was $21.49 \%$. In Aspergillus niger, the degradation efficiency of the hydrogel increases rapidly with time. The degradation rate was $15.9 \%$ at three days and $68.7 \%$ at 21 days. In addition, the degradation effect of mushrooms was higher compared with that of other strains. The experimentally prepared hydrogel was biodegradable and had a good degradation rate in mushrooms. Therefore, even if the hydrogel is disposed to the natural environment, the threat to the environment is minimal [124]. A different study used lysozyme to degrade the cyclic oligosaccharide backbone of a hydrogel by enzymatically hydrolyzing the glycosidic bonds on the hexasaccharide ring. The weight of the hydrogel decreased, indicating that the hydrogel was biodegradable. In addition, analysis of the infrared spectra of the degradation products (obtained on day 14 and day 28) showed that the $\mathrm{C}-\mathrm{O}-\mathrm{C}$ tensile peak intensity of the degradation products decreased after 14 days, whereas the C-O-C tensile peak disappeared after 28 days of degradation. At the same time, analysis of the day 14 and day 28 SEM images of the degraded hydrogel showed that the porous network morphology of the hydrogel was deformed and degraded, showing the degradability property of the hydrogel [125].

When preparing CD-loaded hydrogels, materials that are easily degraded in vivo should be selected as preparation materials. A poly[(R)-3-hydroxybutyrate] fragment was introduced into a hydrogel containing $\mathrm{CD}$ and analysis showed that the copolymer produced was biodegradable under physiological conditions. In addition, the hydrogel formulation was bioabsorbable after administration and was able to dissociate into its components [126]. However, materials used in some heat-sensitive hydrogels are not biodegradable [65]. A previous study explored a hydrogel that could be hydrolyzed by $\alpha$-amylase after the introduction of CD. Moreover, the degradation rate increases when part of the poly- $N$-propylacrylamide molecular chain is replaced by maleic anhydride- $\beta-C D$ (MAH- $\beta$-CD), mainly due to an increase in the hydrolysis of $\beta$-CD by $\alpha$-amylase. Analysis of ${ }^{1} \mathrm{H}$ NMR spectrum shows $\beta$-CD reacts with at least 2 maleic anhydride (MAH) molecules on average. Therefore, MAH- $\beta-\mathrm{CD}$ is a better cross-linking agent in the hydrogel network. At $37^{\circ} \mathrm{C}$, all hydrogels are in a semi-swelled state, and the speed at which enzymes enter the internal network of the hydrogel slows down [127].

When the degradation behavior of hydrogels is studied in an organism, the hydrogel is placed on the organism and then changes of the hydrogel at different times are observed [128]. Using mice as the model to verify the degradation of hydrogel, the degradation rate of the hydrogel was found to be faster under irradiation than without irradiation, indicating that the injectable hydrogel could be rapidly decomposed by photothermal treatment. Moreover, the fluorescence decay rate of the hydrogel was faster after irradiation than without irradiation. On the 4th day, the relative fluorescence signal intensity of the irradiated hydrogel group was about $60 \%$, and the relative fluorescence signal intensity of the non-irradiated hydrogel group was close to $80 \%$. On the 8 th day, the relative fluorescence signal intensity of the non-irradiated hydrogel group was only about $40 \%$, whereas the relative fluorescence signal intensity of the irradiated hydrogel group was about $20 \%$. Therefore, laser irradiation can accelerate the decomposition of the hydrogel nanocomposite system. Light response assisted fluorescence imaging allows visualization of the disassembly of medical biomaterials. The near-infrared light-responsive supramolecular nanocomposite system is widely used to explore the fluorescent imaging tracking process of biomedical materials. The visualization of degradable supramolecular hydrogels on demand helps to eliminate carriers. The controllable non-invasive supramolecular nanocomposite is a promising biomedical material that allows instant stimulation and sustainable monitoring [129]. In another experiment on the degradation of hydrogels in mice during transdermal administration, Zhou et al. discovered that long-term biodegradation of hydrogels administered transdermally in mice may be caused by cross-linked hydrogel side chains. The existence of the cyclodextrin cavity made it difficult for the biological enzymes in the body to contact the hydrogel [96]. 


\section{Conclusions and Perspectives}

As a host molecule that can form host-guest inclusion complexes, CD has great application potential in the fields of medicine and materials science. Promisingly, the administration of CD-containing hydrogels can avoid the annoying side effects of traditional drug administration. In recent years, several studies have shown that hydrogel systems composed of CDs can effectively deliver drugs into target tissues. Especially, many physical and chemical methods have been successfully developed for preparing CD hydrogels.

Presently, the research on CD-containing hydrogel mainly focused on the field of biomedicine. In this review, different methods to design and prepare CD hydrogels are discussed. In addition, the potential applications of drug-loaded CD hydrogels are summarized. The data reviewed here show that introduction of CD improves the properties of the hydrogel and the drug release time of the hydrogels. Interestingly, some CDcontaining hydrogels based on light and heat response have been successfully synthesized. This review broadens our understanding of the development trends in the application of CD-containing hydrogels, which lays the foundation for future clinical research. At the same time, looking forward to the future medical frontiers, we believe that an increasing number of emerging technologies will be introduced to guide the preparation of CDcontaining hydrogels.

Future studies should design drug-loaded CD-containing hydrogels which can withstand factors in the external environment and internal environment in the body to guarantee excellent drug-release dynamics and drug-loading capacity. Moreover, it is of great importance to establish novel methods and tools for monitoring the metabolism of drugs in the body when drug-loaded CD-containing hydrogels enter the body. Meanwhile, attention should be paid to the safety issues associated with hydrogel materials inside the body. How the CD-containing hydrogels are degraded in the body, how they change, and whether they will interact with the body should be closely analyzed. Gratifyingly, more smart stimuli-responsive hydrogels based on CD for drug delivery will be designed and prepared, which can respond to different external and interior environmental stimuli to release drugs. In the future, we can actively take a page from cutting-edge technologies to prepare the CD-containing hydrogels for precision medicine that can accurately load appropriate doses of drugs. In addition, we should have a deep insight into the basic principles of drug loading and release of CD-containing hydrogels in the aspect of sitetargeting, release conditions, dosing intervals for optimal treatment to different diseases. If the above-mentioned problems are fully solved, CD-containing hydrogels are expected to be more widely applied in clinical practice.

Author Contributions: All authors drafted the article and critically modified the important knowledge content, endorsing the final version. Study conception and design: Y.L. and J.-B.W. Literature and data collection: J.L. and B.T. Drafting the article or revising it critically for important intellectual content: Y.L. and J.-B.W. Final approval of the version of the article to be published: J.L., B.T., Y.L. and J.-B.W. All authors have read and agreed to the published version of the manuscript.

Funding: This study was supported by the National Natural Science Foundation of China (31660490), and the Enterprise Cooperation Project (CP/003/2018).

Institutional Review Board Statement: Not applicable.

Informed Consent Statement: Not applicable.

Data Availability Statement: Not applicable.

Conflicts of Interest: The authors declare no conflict of interest. 


$\begin{array}{ll}\text { Abbreviation } & \\ \text { FTIR } & \text { Fourier transform infrared spectroscopy } \\ \text { NMR } & \text { nuclear magnetic resonance } \\ \text { SEM } & \text { scanning electron microscope } \\ \text { XRD } & \text { X-Ray diffraction } \\ \text { S. aureus } & \text { Staphylococcus aureus } \\ \text { P. aeruginosa } & \text { Pseudomonas aeruginosa } \\ \text { E. coli } & \text { Escherichia coli } \\ \text { C. aureus } & \text { Staphylococcus aureus enterotoxin C } \\ \text { Panc 1 } & \text { Human pancreatic cancer cell } \\ \text { U251 } & \text { Human brain glioma U251 cell line } \\ \text { MSTO } & \text { human mesothelioma } \\ \text { NHD } & \text { Fskin fibroblast cells } \\ \text { L929 cells } & \text { L929 mouse fibroblast cells }\end{array}$

\section{References}

1. Champeau, M.; Heinze, D.A.; Viana, T.N.; de Souza, E.R.; Chinellato, A.C.; Titotto, S. 4D printing of hydrogels: A review. Adv. Funct. Mater. 2020, 30, 1910606. [CrossRef]

2. Arslan, M.; Sanyal, R.; Sanyal, A. Cyclodextrin embedded covalently crosslinked networks: Synthesis and applications of hydrogels with nano-containers. Polym. Chem. 2020, 11, 615-629. [CrossRef]

3. Tang, W.; Zou, C.; Da, C.; Cao, Y.; Peng, H. A review on the recent development of cyclodextrin-based materials used in oilfield applications. Carbohydr. Polym. 2020, 240, 116321. [CrossRef]

4. Wang, W.; Yang, Z.; Zhang, A.; Yang, S. Water retention and fertilizer slow release integrated superabsorbent synthesized from millet straw and applied in agriculture. Ind. Crop. Prod. 2020, 160, 113126. [CrossRef]

5. Mandal, A.; Clegg, J.R.; Anselmo, A.C.; Mitragotri, S. Hydrogels in the clinic. Bioeng. Transl. Med. 2020, 5, e10158. [CrossRef] [PubMed]

6. Hosseini, M.S.; Nabid, M.R. Synthesis of chemically cross-linked hydrogel films based on basil seed (Ocimum basilicum L.) mucilage for wound dressing drug delivery applications. Int. J. Biol. Macromol. 2020, 163, 336-347. [CrossRef]

7. Cai, T.; Huo, S.; Wang, T.; Sun, W.; Tong, Z. Self-healable tough supramolecular hydrogels crosslinked by poly-cyclodextrin through host-guest interaction. Carbohydr. Polym. 2018, 193, 54-61. [CrossRef] [PubMed]

8. Tan, S.; Ladewig, K.; Fu, Q.; Blencowe, A.; Qiao, G.G. Cyclodextrin-based supramolecular assemblies and hydrogels: Recent advances and future perspectives. Macromol. Rapid Commun. 2014, 35, 1166-1184. [CrossRef] [PubMed]

9. Cheng, W.; Wang, M.; Chen, M.; Niu, W.; Li, Y.; Wang, Y.; Luo, M.; Xie, C.; Leng, T.; Lei, B. Injectable Antibacterial Antiinflammatory Molecular Hybrid Hydrogel Dressing for Rapid MDRB-Infected Wound Repair and Therapy. Chem. Eng. J. 2021, 409, 128140. [CrossRef]

10. Peng, L.; Chang, L.; Si, M.; Lin, J.; Wei, Y.; Wang, S.; Liu, H.; Han, B.; Jiang, L. Hydrogel-coated dental device with adhesioninhibiting and colony-suppressing properties. ACS Appl. Mater. Interfaces 2020, 12, 9718-9725. [CrossRef]

11. Singh, B.; Kumar, A. Synthesis and characterization of alginate and sterculia gum based hydrogel for brain drug delivery applications. Int. J. Biol. Macromol. 2020, 148, 248-257. [CrossRef]

12. Liu, Y.; Du, J.; Peng, P.; Cheng, R.; Lin, J.; Xu, C.; Yang, H.; Cui, W.; Mao, H.; Li, Y.; et al. Regulation of the inflammatory cycle by a controllable release hydrogel for eliminating postoperative inflammation after discectomy. Bioact. Mater. 2020, 6, 146-157. [CrossRef] [PubMed]

13. Qu, J.; Liang, Y.; Shi, M.; Guo, B.; Gao, Y.; Yin, Z. Biocompatible conductive hydrogels based on dextran and aniline trimer as electro-responsive drug delivery system for localized drug release. Int. J. Biol. Macromol. 2019, 140, 255-264. [CrossRef]

14. Dreiss, C.A. Hydrogel design strategies for drug delivery. Curr. Opin. Colloid Interface Sci. 2020, 48, 1-17. [CrossRef]

15. Peers, S.; Montembault, A.; Ladavière, C. Chitosan hydrogels for sustained drug delivery. J. Control. Release 2020, 326, 150-163. [CrossRef] [PubMed]

16. Krukiewicz, K.; Zak, J.K. Biomaterial-based regional chemotherapy: Local anticancer drug delivery to enhance chemotherapy and minimize its side-effects. Mater. Sci. Eng. C 2016, 62, 927-942. [CrossRef]

17. Li, J.; Mooney, D.J. Designing hydrogels for controlled drug delivery. Nat. Rev. Mater. 2016, 1, 1-17. [CrossRef]

18. Torres-Luna, C.; Fan, X.; Domszy, R.; Hu, N.; Wang, N.S.; Yang, A. Hydrogel-based ocular drug delivery systems for hydrophobic drugs. Eur. J. Pharm. Sci. 2020, 154, 105503. [CrossRef]

19. Szejtli, J. Introduction and general overview of cyclodextrin chemistry. Chem. Rev. 1998, 98, 1743-1754. [CrossRef] [PubMed]

20. Concheiro, A.; Alvarez-Lorenzo, C. Chemically cross-linked and grafted cyclodextrin hydrogels: From nanostructures to drug-eluting medical devices. Adv. Drug Deliv. Rev. 2013, 65, 1188-1203. [CrossRef] [PubMed]

21. Morin-Crini, N.; Crini, G. Environmental applications of water-insoluble $\beta$-cyclodextrin-epichlorohydrin polymers. Prog. Polym. Sci. 2013, 38, 344-368. [CrossRef] 
22. Crini, G.; Fourmentin, S.; Fenyvesi, É.; Torri, G.; Fourmentin, M.; Morin-Crini, N. Fundamentals and applications of cyclodextrins. In Cyclodextrin Fundamentals, Reactivity and Analysis; Springer: Cham, Switzerland, 2018; pp. 1-55.

23. Crini, G. Cyclodextrin-epichlorohydrin polymers synthesis, characterization and applications to wastewater treatment: A review. Enviro. Chem. Lett. 2021, 19, 2383-2403. [CrossRef]

24. Cova, T.F.; Murtinho, D.; Pais, A.A.; Valente, A.J. Combining cellulose and cyclodextrins: Fascinating designs for materials and pharmaceutics. Front. Chem. 2018, 6, 271. [CrossRef]

25. Cova, T.F.; Murtinho, D.; Aguado, R.; Pais, A.A.; Valente, A.J. Cyclodextrin polymers and cyclodextrin-containing polysaccharides for water remediation. Polysaccharides 2021, 2, 16-38. [CrossRef]

26. Pinho, E. Cyclodextrins-based hydrogel. In Plant and Algal Hydrogels for Drug Delivery and Regenerative Medicine; Woodhead Publishing: Sawston, UK, 2021; pp. 113-141.

27. Machín, R.; Isasi, J.R.; Vélaz, I. $\beta$-Cyclodextrin hydrogels as potential drug delivery systems. Carbohydr. Polym. 2012, 87, 2024-2030. [CrossRef]

28. Liu, G.; Yuan, Q.; Hollett, G.; Zhao, W.; Kang, Y.; Wu, J. Cyclodextrin-based host-guest supramolecular hydrogel and its application in biomedical fields. Polym. Chem. 2018, 9, 3436-3449. [CrossRef]

29. Tian, B.; Liu, Y.; Liu, J. Smart stimuli-responsive drug delivery systems based on cyclodextrin: A review. Carbohydr. Polym. 2021, 251, 116871. [CrossRef] [PubMed]

30. Hamedi, H.; Moradi, S.; Hudson, S.M.; Tonelli, A.E. Chitosan based hydrogels and their applications for drug delivery in wound dressings: A review. Carbohydr. Polym. 2018, 199, 445-460. [CrossRef]

31. Tian, B.; Hua, S.; Tian, Y.; Liu, J. Chemical and physical chitosan hydrogels as prospective carriers for drug delivery: A review. J. Mater. Chem. B 2020, 8, 10050-10064. [CrossRef] [PubMed]

32. Zainal, S.H.; Mohd, N.H.; Suhaili, N.; Anuar, F.H.; Lazim, A.M.; Othaman, R. Preparation of cellulose-based hydrogel: A review. J. Mater. Res. Technol. 2021, 10, 935-952. [CrossRef]

33. Chang, C.; Zhang, L. Cellulose-based hydrogels: Present status and application prospects. Carbohydr. Polym. 2011, 84, 40-53. [CrossRef]

34. Guo, X.; Wang, Y.; Qin, Y.; Shen, P.; Peng, Q. Structures, properties and application of alginic acid: A review. Int. J. Biol. Macromol. 2020, 162, 618-628. [CrossRef] [PubMed]

35. Hoffman, A.S. Hydrogels for biomedical applications. Adv. Drug Deliver. Rev. 2012, 64, 18-23. [CrossRef]

36. Patel, S.; Goyal, A. Applications of natural polymer gum arabic: A review. Int. J. Food Prop. 2015, 18, 986-998. [CrossRef]

37. Sennakesavan, G.; Mostakhdemin, M.; Dkhar, L.K.; Seyfoddin, A.; Fatihhi, S.J. Acrylic acid/acrylamide based hydrogels and its properties-A review. Polym. Degrad. Stabil. 2020, 180, 109308. [CrossRef]

38. Rodríguez-Rodríguez, R.; Espinosa-Andrews, H.; Velasquillo-Martínez, C.; García-Carvajal, Z.Y. Composite hydrogels based on gelatin, chitosan and polyvinyl alcohol to biomedical applications: A review. Int. J. Polym. Mater. Polym. Biomater. 2020, 69, 1-20. [CrossRef]

39. Timofejeva, A.; D’Este, M.; Loca, D. Calcium phosphate/polyvinyl alcohol composite hydrogels: A review on the freeze-thawing synthesis approach and applications in regenerative medicine. Eur. Polym. J. 2017, 95, 547-565. [CrossRef]

40. Liu, Q.; Yang, D.; Shang, T.; Guo, L.; Yang, B.; Xu, X. Chain conformation transition induced host-guest assembly between triple helical curdlan and $\beta$-CD for drug delivery. Biomater. Sci. 2020, 8, 1638-1648. [CrossRef]

41. Tian, B.; Hua, S.; Liu, J. Cyclodextrin-based delivery systems for chemotherapeutic anticancer drugs: A review. Carbohydr. Polym. 2020, 232, 115805. [CrossRef]

42. Tian, B.; Liu, Y.; Liu, J. Cyclodextrin as a magic switch in covalent and non-covalent anticancer drug release systems. Carbohydr. Polym. 2020, 242, 116401. [CrossRef] [PubMed]

43. Cooper, R.C.; Yang, H. Hydrogel-based ocular drug delivery systems: Emerging fabrication strategies, applications, and bench-to-bedside manufacturing considerations. J. Control. Release 2019, 306, 29-39. [CrossRef]

44. Gunathilake, T.M.S.U.; Ching, Y.C.; Chuah, C.H.; Abd Rahman, N.; Nai-Shang, L. Recent advances in celluloses and their hybrids for stimuli-responsive drug delivery. Int. J. Biol. Macromol. 2020, 158, 670-688. [CrossRef]

45. Soppimath, K.S.; Aminabhavi, T.M.; Dave, A.M.; Kumbar, S.G.; Rudzinski, W.E. Stimulus-responsive "smart" hydrogels as novel drug delivery systems. Drug Dev. Ind. Pharm. 2002, 28, 957-974. [CrossRef] [PubMed]

46. Mignon, A.; De Belie, N.; Dubruel, P.; Van Vlierberghe, S. Superabsorbent polymers: A review on the characteristics and applications of synthetic, polysaccharide-based, semi-synthetic and 'smart'derivatives. Eur. Polym. J. 2019, 117, 165-178. [CrossRef]

47. Zhang, K.; Feng, Q.; Fang, Z.; Gu, L.; Bian, L. Structurally Dynamic Hydrogels for Biomedical Applications: Pursuing a Fine Balance between Macroscopic Stability and Microscopic Dynamics. Chem. Rev. 2021, 121, 11149-11193. [CrossRef] [PubMed]

48. Kiti, K.; Suwantong, O. Bilayer wound dressing based on sodium alginate incorporated with curcumin- $\beta$-cyclodextrin inclusion complex/chitosan hydrogel. Int. J. Biol. Macromol. 2020, 164, 4113-4124. [CrossRef] [PubMed]

49. Moradi, S.; Barati, A.; Tonelli, A.E.; Hamedi, H. Chitosan-based hydrogels loading with thyme oil cyclodextrin inclusion compounds: From preparation to characterization. Eur. Polym. J. 2020, 122, 109303. [CrossRef]

50. Barragán, C.A.R.; Balleza, E.R.M.; García-Uriostegui, L.; Ortega, J.A.A.; Toríz, G.; Delgado, E. Rheological characterization of new thermosensitive hydrogels formed by chitosan, glycerophosphate, and phosphorylated $\beta$-cyclodextrin. Carbohydr. Polym. 2018, 201, 471-481. [CrossRef] 
51. Das, S.; Subuddhi, U. Cyclodextrin mediated controlled release of naproxen from pH-sensitive chitosan/poly (vinyl alcohol) hydrogels for colon targeted delivery. Ind. Eng. Chem. Res. 2013, 52, 14192-14200. [CrossRef]

52. Choi, J.H.; Park, A.; Lee, W.; Youn, J.; Rim, M.A.; Kim, W.; Kim, N.; Song, J.E.; Khang, G. Preparation and characterization of an injectable dexamethasone-cyclodextrin complexes-loaded gellan gum hydrogel for cartilage tissue engineering. J. Control. Release 2020, 327, 747-765. [CrossRef]

53. Bianchi, S.E.; Machado, B.E.; da Silva, M.G.; da Silva, M.M.; Dal Bosco, L.; Marques, M.S.; Horn, A.P.; Persich, L.; Geller, F.C.; Argenta, D.; et al. Coumestrol/hydroxypropyl- $\beta$-cyclodextrin association incorporated in hydroxypropyl methylcellulose hydrogel exhibits wound healing effect: In vitro and in vivo study. Eur. J. Pharm. Sci. 2018, 119, 179-188. [CrossRef] [PubMed]

54. Xiao, L.; Poudel, A.J.; Huang, L.; Wang, Y.; Abdalla, A.M.; Yang, G. Nanocellulose hyperfine network achieves sustained release of berberine hydrochloride solubilized with $\beta$-cyclodextrin for potential anti-infection oral administration. Int. J. Biol. Macromol. 2020, 153, 633-640. [CrossRef] [PubMed]

55. Chunshom, N.; Chuysinuan, P.; Thanyacharoen, T.; Techasakul, S.; Ummartyotin, S. Development of gallic acid/cyclodextrin inclusion complex in freeze-dried bacterial cellulose and poly (vinyl alcohol) hydrogel: Controlled-release characteristic and antioxidant properties. Mater. Chem. Phys. 2019, 232, 294-300. [CrossRef]

56. Eid, M.; Sobhy, R.; Zhou, P.; Wei, X.; Wu, D.; Li, B. $\beta$-cyclodextrin-soy soluble polysaccharide based core-shell bionanocomposites hydrogel for vitamin E swelling controlled delivery. Food Hydrocoll. 2020, 104, 105751. [CrossRef]

57. Zhang, B.; Wang, J.; Li, Z.; Ma, M.; Jia, S.; Li, X. Use of hydroxypropyl $\beta$-cyclodextrin as a dual functional component in xanthan hydrogel for sustained drug release and antibacterial activity. Colloid Surf. A 2020, 587, 124368. [CrossRef]

58. Yu, B.; Zhan, A.; Liu, Q.; Ye, H.; Huang, X.; Shu, Y.; Yang, Y.; Liu, H. A designed supramolecular cross-linking hydrogel for the direct, convenient, and efficient administration of hydrophobic drugs. Int. J. Pharm. 2020, 578, 119075. [CrossRef]

59. Kim, C.; Jeong, D.; Kim, S.; Kim, Y.; Jung, S. Cyclodextrin functionalized agarose gel with low gelling temperature for controlled drug delivery systems. Carbohydr. Polym. 2019, 222, 115011. [CrossRef]

60. Malik, N.S.; Ahmad, M.; Minhas, M.U. Cross-linked $\beta$-cyclodextrin and carboxymethyl cellulose hydrogels for controlled drug delivery of acyclovir. PLOS ONE 2017, 12, e0172727. [CrossRef] [PubMed]

61. Ghorpade, V.S.; Yadav, A.V.; Dias, R.J. Citric acid crosslinked $\beta$-cyclodextrin/carboxymethylcellulose hydrogel films for controlled delivery of poorly soluble drugs. Carbohydr. Polym. 2017, 164, 339-348. [CrossRef]

62. Amiel, A.G.; Palomino-Durand, C.; Maton, M.; Lopez, M.; Cazaux, F.; Chai, F.; Neut, C.; Foligné, B.; Martel, B.; Blanchemain, N. Designed sponges based on chitosan and cyclodextrin polymer for a local release of ciprofloxacin in diabetic foot infections. Int. J. Pharm. 2020, 587, 119677. [CrossRef] [PubMed]

63. Xia, N.; Wan, W.; Zhu, S.; Liu, Q. Preparation of crystalline nanocellulose/hydroxypropyl $\beta$-cyclodextrin/carboxymethyl cellulose polyelectrolyte complexes and their controlled release of neohesperidin-copper (II) in vitro. Int. J. Biol. Macromol. 2020, 163, 1518-1528. [CrossRef]

64. Pooresmaeil, M.; Namazi, H. Preparation and characterization of polyvinyl alcohol/ $\beta$-cyclodextrin/GO-Ag nanocomposite with improved antibacterial and strength properties. Polym. Adv. Technol. 2019, 30, 447-456. [CrossRef]

65. Song, X.; Zhang, Z.; Zhu, J.; Wen, Y.; Zhao, F.; Lei, L.; Phan-Thien, N.; Khoo, B.C.; Li, J. Thermoresponsive hydrogel induced by dual supramolecular assemblies and its controlled release property for enhanced anticancer drug delivery. Biomacromolecules 2020, 21, 1516-1527. [CrossRef]

66. Li, R.; Guan, X.; Lin, X.; Guan, P.; Zhang, X.; Rao, Z.; Du, L.; Zhao, J.; Rong, J.; Zhao, J. Poly (2-hydroxyethyl methacrylate)/ $\beta$ cyclodextrin-hyaluronan contact lens with tear protein adsorption resistance and sustained drug delivery for ophthalmic diseases. Acta Biomater. 2020, 110, 105-118. [CrossRef] [PubMed]

67. Grimaudo, M.A.; Nicoli, S.; Santi, P.; Concheiro, A.; Alvarez-Lorenzo, C. Cyclosporine-loaded cross-linked inserts of sodium hyaluronan and hydroxypropyl- $\beta$-cyclodextrin for ocular administration. Carbohydr. Polym. 2018, 201, 308-316. [CrossRef] [PubMed]

68. Davis, M.E.; Brewster, M.E. Cyclodextrin-based pharmaceutics: Past, present and future. Nat. Rev. Drug Discov. 2004, 3, 1023-1035. [CrossRef]

69. Loftsson, T.; Duchêne, D. Cyclodextrins and their pharmaceutical applications. Int. J. Pharm. 2007, 329, 1-11. [CrossRef]

70. Öztürk-Atar, K.; Kaplan, M.; Çalış, S. Development and evaluation of polymeric micelle containing tablet formulation for poorly water-soluble drug: Tamoxifen citrate. Drug Dev. Ind. Pharm. 2020, 46, 1695-1704. [CrossRef]

71. Tian, B.; Xiao, D.; Hei, T.; Ping, R.; Hua, S.; Liu, J. The application and prospects of cyclodextrin inclusion complexes and polymers in the food industry: A review. Polym. Int. 2020, 69, 597-603. [CrossRef]

72. Wankar, J.; Kotla, N.G.; Gera, S.; Rasala, S.; Pandit, A.; Rochev, Y.A. Recent advances in host-guest self-assembled cyclodextrin carriers: Implications for responsive drug delivery and biomedical engineering. Adv. Funct. Mater. 2020, 30, 1909049. [CrossRef]

73. Tejashri, G.; Amrita, B.; Darshana, J. Cyclodextrin based nanosponges for pharmaceutical use: A review. Acta Pharm. 2013, 63, 335-358. [CrossRef]

74. Liu, Z.; Ye, L.; Xi, J.; Wang, J.; Feng, Z.G. Cyclodextrin Polymers: Structure, Synthesis, and Use as Drug Carriers. Prog. Polym. Sci. 2021, 118, 101408. [CrossRef]

75. Zhang, M.; Wang, J.; Jin, Z. Supramolecular hydrogel formation between chitosan and hydroxypropyl $\beta$-cyclodextrin via Diels-Alder reaction and its drug delivery. Int. J. Biol. Macromol. 2018, 114, 381-391. [CrossRef] 
76. Gami, P.; Kundu, D.; Seera, S.D.K.; Banerjee, T. Chemically crosslinked xylan- $\beta$-Cyclodextrin hydrogel for the in vitro delivery of curcumin and 5-Fluorouracil. Int. J. Biol. Macromol. 2020, 158, 18-31. [CrossRef] [PubMed]

77. Blanco-Fernandez, B.; Lopez-Viota, M.; Concheiro, A.; Alvarez-Lorenzo, C. Synergistic performance of cyclodextrin-agar hydrogels for ciprofloxacin delivery and antimicrobial effect. Carbohydr. Polym. 2011, 85, 765-774. [CrossRef]

78. Otero-Espinar, F.J.; Torres-Labandeira, J.J.; Alvarez-Lorenzo, C.; Blanco-Méndez, J. Cyclodextrins in drug delivery systems. J. Drug Deliv. Sci. Tec. 2010, 20, 289-301. [CrossRef]

79. Li, J.; Loh, X.J. Cyclodextrin-based supramolecular architectures: Syntheses, structures, and applications for drug and gene delivery. Adv. Drug Deliver. Rev. 2008, 60, 1000-1017. [CrossRef]

80. Sharaf, S.; El-Naggar, M.E. Wound dressing properties of cationized cotton fabric treated with carrageenan/cyclodextrin hydrogel loaded with honey bee propolis extract. Int. J. Biol. Macromol. 2019, 133, 583-591. [CrossRef] [PubMed]

81. Hewitt, M.G.; Morrison, P.W.; Boostrom, H.M.; Morgan, S.R.; Fallon, M.; Lewis, P.N. In vitro topical delivery of chlorhexidine to the cornea: Enhancement using drug-loaded contact lenses and $\beta$-cyclodextrin complexation, and the importance of simulating tear irrigation. Mol. Pharm. 2020, 17, 1428-1441. [CrossRef] [PubMed]

82. Gupta, A.; Briffa, S.M.; Swingler, S.; Gibson, H.; Kannappan, V.; Adamus, G.; Kowalczuk, M.; Martin, C.; Radecka, I. Synthesis of silver nanoparticles using curcumin-cyclodextrins loaded into bacterial cellulose-based hydrogels for wound dressing applications. Biomacromolecules 2020, 21, 1802-1811. [CrossRef] [PubMed]

83. Gularte, M.S.; Quadrado, R.F.; Pedra, N.S.; Soares, M.S.; Bona, N.P.; Spanevello, R.M.; Fajardo, A.R. Preparation, characterization and antitumor activity of a cationic starch-derivative membrane embedded with a $\beta$-cyclodextrin/curcumin inclusion complex. Int. J. Biol. Macromol. 2020, 148, 140-152. [CrossRef] [PubMed]

84. Moradi, S.; Barati, A.; Tonelli, A.E.; Hamedi, H. Effect of clinoptilolite on structure and drug release behavior of chitosan/thyme oil $\gamma$-Cyclodextrin inclusion compound hydrogels. J. Appl. Polym. Sci. 2021, 138, 49822. [CrossRef]

85. Moradi, S.; Barati, A.; Salehi, E.; Tonelli, A.E.; Hamedi, H. Preparation and characterization of chitosan based hydrogels containing cyclodextrin inclusion compounds or nanoemulsions of thyme oil. Polym. Int. 2019, 68, 1891-1902. [CrossRef]

86. Sajeesh, S.; Bouchemal, K.; Marsaud, V.; Vauthier, C.; Sharma, C.P. Cyclodextrin complexed insulin encapsulated hydrogel microparticles: An oral delivery system for insulin. J. Control. Release 2010, 147, 377-384. [CrossRef]

87. Okubo, M.; Iohara, D.; Anraku, M.; Higashi, T.; Uekama, K.; Hirayama, F. A thermoresponsive hydrophobically modified hydroxypropylmethylcellulose/cyclodextrin injectable hydrogel for the sustained release of drugs. Int. J. Pharm. 2020, 575, 118845. [CrossRef]

88. Sarkar, A.; Mackie, A.R. Engineering oral delivery of hydrophobic bioactives in real-world scenarios. Curr. Opin. Colloid Interface Sci. 2020, 48, 40-52. [CrossRef]

89. Xiang, J.; Shen, L.; Hong, Y. Status and future scope of hydrogels in wound healing: Synthesis, materials and evaluation. Eur. Polym. J. 2020, 130, 109609. [CrossRef]

90. Zhang, L.; Liu, M.; Zhang, Y.; Pei, R. Recent progress of highly adhesive hydrogels as wound dressings. Biomacromolecules 2020, 21, 3966-3983. [CrossRef] [PubMed]

91. Klotz, S.A.; Penn, C.C.; Negvesky, G.J.; Butrus, S.I. Fungal and parasitic infections of the eye. Clin. Microbiol. Rev. 2000, 13, 662-685. [CrossRef]

92. Jumelle, C.; Gholizadeh, S.; Annabi, N.; Dana, R. Advances and limitations of drug delivery systems formulated as eye drops. J. Control. Release 2020, 321, 1-22. [CrossRef]

93. El-Zeiny, H.M.; Abukhadra, M.R.; Sayed, O.M.; Osman, A.H. Ahmed, S.A. Insight into novel $\beta$-cyclodextrin-grafted-poly ( $\mathrm{N}$-vinylcaprolactam) nanogel structures as advanced carriers for 5-fluorouracil: Equilibrium behavior and pharmacokinetic modeling. Colloid Surf. A 2020, 586, 124197. [CrossRef]

94. Moncada-Basualto, M.; Matsuhiro, B.; Mansilla, A.; Lapier, M.; Maya, J.D.; Olea-Azar, C. Supramolecular hydrogels of $\beta$ cyclodextrin linked to calcium homopoly-l-guluronate for release of coumarins with trypanocidal activity. Carbohydr. Polym. 2019, 204, 170-181. [CrossRef]

95. Gholibegloo, E.; Mortezazadeh, T.; Salehian, F.; Ramazani, A.; Amanlou, M.; Khoobi, M. Improved curcumin loading, release, solubility and toxicity by tuning the molar ratio of cross-linker to $\beta$-cyclodextrin. Carbohydr. Polym. 2019, 213, 70-78. [CrossRef]

96. Zhou, X.; Luo, Z.; Baidya, A.; Kim, H.J.; Wang, C.; Jiang, X.; Qu, M.; Zhu, J.; Ren, L.; Vajhadin, F.; et al. Biodegradable $\beta$-Cyclodextrin Conjugated Gelatin Methacryloyl Microneedle for Delivery of Water-Insoluble Drug. Adv. Healthc. Mater. 2020, 9 , 2000527. [CrossRef]

97. Khalid, Q.; Ahmad, M.; Minhas, M.U.; Batool, F.; Malik, N.S.; Rehman, M. Novel $\beta$-cyclodextrin nanosponges by chain growth condensation for solubility enhancement of dexibuprofen: Characterization and acute oral toxicity studies. J. Drug Deliv. Sci. Technol. 2021, 61, 102089. [CrossRef]

98. Soleimani, K.; Arkan, E.; Derakhshankhah, H.; Haghshenas, B.; Jahanban-Esfahlan, R.; Jaymand, M. A novel bioreducible and $\mathrm{pH}$-responsive magnetic nanohydrogel based on $\beta$-cyclodextrin for chemo/hyperthermia therapy of cancer. Carbohydr. Polym. 2020, 252, 117229. [CrossRef]

99. Fiorica, C.; Palumbo, F.S.; Pitarresi, G.; Puleio, R.; Condorelli, L.; Collura, G.; Giammona, G. A hyaluronic acid/cyclodextrin based injectable hydrogel for local doxorubicin delivery to solid tumors. Int. J. Pharm. 2020, 589, 119879. [CrossRef] [PubMed] 
100. Das, M.; Nariya, P.; Joshi, A.; Vohra, A.; Devkar, R.; Seshadri, S.; Thakore, S. Carbon nanotube embedded cyclodextrin polymer derived injectable nanocarrier: A multiple faceted platform for stimulation of multi-drug resistance reversal. Carbohydr. Polym. 2020, 247, 116751. [CrossRef] [PubMed]

101. Lee, H.J.; Le, P.T.; Kwon, H.J.; Park, K.D. Supramolecular assembly of tetronic-adamantane and poly ( $\beta$-cyclodextrin) as injectable shear-thinning hydrogels. J. Mat. Chem. B 2019, 7, 3374-3382. [CrossRef]

102. Yang, Y.; Liu, Y.; Chen, S.; Cheong, K.L.; Teng, B. Carboxymethyl $\beta$-cyclodextrin grafted carboxymethyl chitosan hydrogel-based microparticles for oral insulin delivery. Carbohydr. Polym. 2020, 246, 116617. [CrossRef] [PubMed]

103. Hossen, S.; Hossain, M.K.; Basher, M.K.; Mia, M.N.H.; Rahman, M.T.; Uddin, M.J. Smart nanocarrier-based drug delivery systems for cancer therapy and toxicity studies: A review. J. Adv. Res. 2019, 15, 1-18. [CrossRef]

104. Luo, J.; Shi, X.; Li, L.; Tan, Z.; Feng, F.; Li, J.; Pang, M.; Wang, X.; He, L. An injectable and self-healing hydrogel with controlled release of curcumin to repair spinal cord injury. Bioact. Mater. 2021, 6, 4816-4829. [CrossRef] [PubMed]

105. Gull, N.; Khan, S.M.; Butt, O.M.; Islam, A.; Shah, A.; Jabeen, S.; Khan, S.U.; Khan, A.; Khan, R.U.; Butt, M.T.Z. Inflammation targeted chitosan-based hydrogel for controlled release of diclofenac sodium. Int. J. Biol. Macromol. 2020, 162, 175-187. [CrossRef]

106. Ata, S.; Rasool, A.; Islam, A.; Bibi, I.; Rizwan, M.; Azeem, M.K.; Iqbal, M. Loading of Cefixime to pH sensitive chitosan based hydrogel and investigation of controlled release kinetics. Int. J. Biol. Macromol. 2020, 155, 1236-1244. [CrossRef]

107. Jeong, K.; Yu, Y.J.; You, J.Y.; Rhee, W.J.; Kim, J.A. Exosome-mediated microRNA-497 delivery for anti-cancer therapy in a microfluidic 3D lung cancer model. Lab. Chip 2020, 20, 548-557. [CrossRef]

108. Yu, Y.; Xu, S.; Yu, S.; Li, J.; Tan, G.; Li, S.; Pan, W. A Hybrid Genipin-Cross-Linked Hydrogel/Nanostructured Lipid Carrier for Ocular Drug Delivery: Cellular, ex Vivo, and in Vivo Evaluation. ACS Biomater. Sci. Eng. 2020, 6, 1543-1552. [CrossRef]

109. Utine, C.A.; Stern, M.; Akpek, E.K. Clinical review: Topical ophthalmic use of cyclosporin A. Ocul. Immunol. Inflamm. 2010, 18, 352-361. [CrossRef] [PubMed]

110. Periman, L.M.; Mah, F.S.; Karpecki, P.M. A review of the mechanism of action of cyclosporine A: The role of cyclosporine a in dry eye disease and recent formulation developments. Clin. Ophthalmol. 2020, 14, 4187. [CrossRef] [PubMed]

111. Singh, M.; Bharadwaj, S.; Lee, K.E.; Kang, S.G. Therapeutic nanoemulsions in ophthalmic drug administration: Concept in formulations and characterization techniques for ocular drug delivery. J. Control. Release 2020, 328, 895-916. [CrossRef]

112. Campos, P.M.; Petrilli, R.; Lopez, R.F. The prominence of the dosage form design to treat ocular diseases. Int. J. Pharm. 2020, 586, 119577. [CrossRef]

113. Pradhan, S.; Keller, K.A.; Sperduto, J.L.; Slater, J.H. Fundamentals of laser-based hydrogel degradation and applications in cell and tissue engineering. Adv. Healthc. Mater. 2017, 6, 1700681. [CrossRef]

114. Tondera, C.; Hauser, S.; Krüger-Genge, A.; Jung, F.; Neffe, A.T.; Lendlein, A.; Klopfleisch, R.; Steinbach, J.; Neuber, C.; Pietzsch, J. Gelatin-based hydrogel degradation and tissue interaction in vivo: Insights from multimodal preclinical imaging in immunocompetent nude mice. Theranostics 2016, 6, 2114. [CrossRef] [PubMed]

115. Yang, R.; Liu, X.; Ren, Y.; Xue, W.; Liu, S.; Wang, P.; Zhao, M.; Xu, H.; Chi, B. Injectable adaptive self-healing hyaluronic acid/poly ( $\gamma$-glutamic acid) hydrogel for cutaneous wound healing. Acta Biomater. 2021, 127, 102-115. [CrossRef]

116. Liu, C.; Zhang, Z.; Liu, X.; Ni, X.; Li, J. Gelatin-based hydrogels with $\beta$-cyclodextrin as a dual functional component for enhanced drug loading and controlled release. RSC Adv. 2013, 3, 25041-25049. [CrossRef]

117. Li, J. Self-assembled supramolecular hydrogels based on polymer-cyclodextrin inclusion complexes for drug delivery. NPG Asia Mater. 2010, 2, 112-118. [CrossRef]

118. Jalalvandi, E.; Cabral, J.; Hanton, L.R.; Moratti, S.C. Cyclodextrin-polyhydrazine degradable gels for hydrophobic drug delivery. Mater. Sci. Eng. C 2016, 69, 144-153. [CrossRef] [PubMed]

119. Kersani, D.; Mougin, J.; Lopez, M.; Degoutin, S.; Tabary, N.; Cazaux, F.; Janus, L.; Maton, M.; Chai, F.; Sobocinski, J.; et al. Stent coating by electrospinning with chitosan/poly-cyclodextrin based nanofibers loaded with simvastatin for restenosis prevention. Eur. J. Pharm. Biopharm. 2020, 150, 156-167. [CrossRef]

120. Yang, N.; Wang, Y.; Zhang, Q.; Chen, L.; Zhao, Y. In situ formation of poly (thiolated chitosan-co-alkylated $\beta$-cyclodextrin) hydrogels using click cross-linking for sustained drug release. J. Mater. Sci. 2019, 54, 1677-1691. [CrossRef]

121. Sheng, J.; Wang, Y.; Xiong, L.; Luo, Q.; Li, X.; Shen, Z.; Zhu, W. Injectable doxorubicin-loaded hydrogels based on dendron-like $\beta$-cyclodextrin-poly (ethylene glycol) conjugates. Polym. Chem. 2017, 8, 1680-1688. [CrossRef]

122. Van de Manakker, F.; Braeckmans, K.; Morabit, N.E.; De Smedt, S.C.; van Nostrum, C.F.; Hennink, W.E. Protein-Release Behavior of Self-Assembled PEG- $\beta$-Cyclodextrin/PEG-Cholesterol Hydrogels. Adv. Funct. Mater. 2009, 19, 2992-3001. [CrossRef]

123. Yu, J.; Fan, H.; Huang, J.; Chen, J. Fabrication and evaluation of reduction-sensitive supramolecular hydrogel based on cyclodextrin/polymer inclusion for injectable drug-carrier application. Soft Matter 2011, 7, 7386-7394. [CrossRef]

124. Huang, Z.; Liu, S.; Zhang, B.; Wu, Q. Preparation and swelling behavior of a novel self-assembled $\beta$-cyclodextrin/acrylic acid/sodium alginate hydrogel. Carbohydr. Polym. 2014, 113, 430-437. [CrossRef] [PubMed]

125. Roy, A.; Maity, P.P.; Dhara, S.; Pal, S. Biocompatible, stimuli-responsive hydrogel of chemically crosslinked $\beta$-cyclodextrin as amoxicillin carrier. J. Appl. Polym. Sci. 2018, 135, 45939. [CrossRef]

126. Li, J.; Li, X.; Ni, X.; Wang, X.; Li, H.; Leong, K.W. Self-assembled supramolecular hydrogels formed by biodegradable PEOPHB-PEO triblock copolymers and $\alpha$-cyclodextrin for controlled drug delivery. Biomaterials 2006, 27, 4132-4140. [CrossRef] [PubMed] 
127. Wang, Y.; Yang, N.; Wang, D.; He, Y.; Chen, L.; Zhao, Y. Poly (MAH- $\beta$-cyclodextrin-co-NIPAAm) hydrogels with drug hosting and thermo/pH-sensitive for controlled drug release. Polym. Degrad. Stabil. 2018, 147, 123-131. [CrossRef]

128. Yoon, S.J.; Hyun, H.; Lee, D.W.; Yang, D.H. Visible light-cured glycol chitosan hydrogel containing a beta-cyclodextrin-curcumin inclusion complex improves wound healing in vivo. Molecules 2017, 22, 1513. [CrossRef]

129. Liang, J.; Dong, X.; Wei, C.; Ma, G.; Liu, T.; Kong, D.; Lv, F. A visible and controllable porphyrin-poly (ethylene glycol)/ $\alpha-$ cyclodextrin hydrogel nanocomposites system for photo response. Carbohydr. Polym. 2017, 175, 440-449. [CrossRef] 